\title{
Synaptic Basis for Differential Orientation Selectivity between Complex and Simple Cells in Mouse Visual Cortex
}

\author{
다a-tang Li, ${ }^{1,4}$ Bao-hua Liu, ${ }^{1}$ ○Xiao-lin Chou, ${ }^{1,4}$ Li I. Zhang, ${ }^{1,3}$ and Huizhong W. Tao ${ }^{1,2}$ \\ 'Zilkha Neurogenetic Institute, ${ }^{2}$ Department of Cell and Neurobiology, ${ }^{3}$ Department of Physiology and Biophysics, and ${ }^{4}$ Graduate Programs, Keck School of \\ Medicine, University of Southern California, Los Angeles, California 90033
}

In the primary visual cortex $(\mathrm{V} 1)$, orientation-selective neurons can be categorized into simple and complex cells primarily based on their receptive field (RF) structures. In mouse V1, although previous studies have examined the excitatory/inhibitory interplay underlying orientation selectivity $(\mathrm{OS})$ of simple cells, the synaptic bases for that of complex cells have remained obscure. Here, by combining in vivo loose-patch and whole-cell recordings, we found that complex cells, identified by their overlapping on/off subfields, had significantly weaker OS than simple cells at both spiking and subthreshold membrane potential response levels. Voltage-clamp recordings further revealed that although excitatory inputs to complex and simple cells exhibited a similar degree of $O S$, inhibition in complex cells was more narrowly tuned than excitation, whereas in simple cells inhibition was more broadly tuned than excitation. The differential inhibitory tuning can primarily account for the difference in OS between complex and simple cells. Interestingly, the differential synaptic tuning correlated well with the spatial organization of synaptic input: the inhibitory visual RF in complex cells was more elongated in shape than its excitatory counterpart and also was more elongated than that in simple cells. Together, our results demonstrate that OS of complex and simple cells is differentially shaped by cortical inhibition based on its orientation tuning profile relative to excitation, which is contributed at least partially by the spatial organization of RFs of presynaptic inhibitory neurons.

Key words: excitation-inhibition balance; in vivo whole-cell recording; orientation tuning; receptive field; synaptic input

\section{Significance Statement}

Simple and complex cells, two classes of principal neurons in the primary visual cortex (V1), are generally thought to be equally selective for orientation. In mouse V1, we report that complex cells, identified by their overlapping on/off subfields, has significantly weaker orientation selectivity $(\mathrm{OS})$ than simple cells. This can be primarily attributed to the differential tuning selectivity of inhibitory synaptic input: inhibition in complex cells is more narrowly tuned than excitation, whereas in simple cells inhibition is more broadly tuned than excitation. In addition, there is a good correlation between inhibitory tuning selectivity and the spatial organization of inhibitory inputs. These complex and simple cells with differential degree of OS may provide functionally distinct signals to different downstream targets.

\section{Introduction}

Orientation selectivity (OS) of neuronal responses is considered to be fundamental for visual perception of contours. In the primary visual cortex (V1), orientation-selective principal neurons

\footnotetext{
Received Dec. 25, 2014; revised June 29, 2015; accepted July 5, 2015.

Author contributions:Y.-t.L., L.I.Z., and H.W.T. designed research;Y.-t.L. and B.-h.L. performed research; Y.-t.L., B.-h.L., and X.-I.C. analyzed data; Y.-t.L., L.I.I., and H.W.T. wrote the paper.

This work was supported by grants from the National Institutes of Health (EY019049) and Kirchgessner Foundation to H.W.T., and National Institutes of Health Grant DC008983 to L.I.Z

The authors declare no competing financial interests.

Correspondence should be addressed to Huizhong W. Tao, University of Southern California, 1501 San Pablo Street, ZNI 339, Los Angeles, CA 90033. E-mail: htao@usc.edu.

B.-h. Liu's present address: Center for Neural Circuits and Behavior, University of California at San Diego, 9500 Gilman Drive, La Jolla, CA 92093.

DOI:10.1523/JNEUROSCI.5246-14.2015

Copyright $\odot 2015$ the authors $\quad 0270-6474 / 15 / 3511081-13 \$ 15.00 / 0$
}

are categorized into two distinct classes, simple and complex cells, based on their spike responses to either flashing or drifting stimuli (Hubel and Wiesel, 1962; Campbell et al., 1968; De Valois et al., 1982; Skottun et al., 1991; Niell and Stryker, 2008). The two cell types can be primarily distinguished by their different receptive field (RF) structures: simple cells have spatially segregated on and off subfields, while complex cells display overlapping on and off subfields (Hubel and Wiesel, 1962; Heggelund, 1986). Although simple and complex cells are generally considered to be equally selective for stimulus orientation, there have been results from several studies in cats and monkeys suggesting that complex cells are somewhat less selectively tuned than simple cells (Henry et al., 1974; Rose and Blakemore, 1974; Watkins and Berkley, 1974; Ikeda and Wright, 1975; Schiller et al., 1976; De Valois et al., 1982; Ringach et al., 2002). 
The mechanisms for the potential differential degree of OS between simple and complex cells have not been explored previously. In the hierarchical model for visual processing (Hubel and Wiesel, 1962), it is thought that complex cells receive converging inputs from simple cells displaying similar orientation preferences, thus inheriting OS from the group of presynaptic neurons. It is certainly possible that the presynaptic simple cells do not perfectly register in orientation tuning profile, and that the convergence of inputs from them results in an averaging/smoothing effect, leading to the reduced tuning selectivity of the postsynaptic complex cell. This mechanism may be reflected by more weakly tuned excitatory input in complex than simple cells. On the other hand, in our previous study of simple cells in mouse V1, we have demonstrated that their orientation tuning is critically shaped by the interplay between moderately tuned excitation and even more broadly tuned inhibition as compared with excitation (Liu et al., 2011). The latter appears to play an essential role in sharpening OS of simple cells (Liu et al., 2011). Thus, an alternative mechanism could be that a differential excitatory/inhibitory interplay results in relatively weak selectivity of complex cells. To further understand the synaptic bases for OS in mouse V1, we examined complex cells primarily in layer $2 / 3$ by combining in vivo cell-attached and whole-cell voltage-clamp recordings. Our results indicated that the relatively weak OS of complex cells compared with simple cells could be primarily attributed to an inhibitory synaptic mechanism: although there was no significant difference in excitation between simple and complex cells, complex cells received more narrowly tuned inhibitory inputs compared with their excitation, in contrast to the more broadly tuned inhibition in simple cells. Finally, the differential orientation tuning of inhibitory input correlated well with the spatial organization of its visual RF.

\section{Materials and Methods}

Animal preparation. All experimental procedures used in this study were approved by the Animal Care and Use Committee of the University of Southern California. Female adult (12-16 weeks) C57BL/6 mice were used. Animals were sedated with an intramuscular injection of chlorprothixene $(4 \mathrm{mg} / \mathrm{ml})$ and anesthetized with urethane $(1.2 \mathrm{~g} / \mathrm{kg}$, i.p., at $20 \%$ $\mathrm{w} / \mathrm{v}$ in saline). Surgical procedure was performed to expose the visual cortex as previously described (Niell and Stryker, 2008; Liu et al., 2009, 2010). Eyelids were sutured during the surgical procedure. After the surgery, the right eyelid was reopened. The eye was rinsed with saline and a thin layer of silicone oil (30,000 centistokes) was applied to prevent drying while allowing clear optical transmission. Multiunit recordings were performed to determine the retinotopic map and location of V1, as previously described (Liu et al., 2009, 2010). The eye movement and RF drift of single units were negligible within the recording time windows (Mangini and Pearlman, 1980; Liu et al., 2009).

In vivo electrophysiology. Cell-attached and whole-cell recordings were performed with an Axopatch 200B (Molecular Devices) according to previous studies (Moore and Nelson, 1998; Zhang et al., 2003; Liu et al., $2010)$. The patch pipette had a tip opening of $\sim 2 \mu \mathrm{m}(4-6 \mathrm{M} \Omega)$. For most whole-cell recordings, we used a $\mathrm{Cs}^{+}$-based intrapipette solution containing the following (in $\mathrm{mm}$ ): 125 Cs-gluconate, 5 TEA-Cl, 4 MgATP, 0.3 GTP, 8 phosphocreatine, 10 HEPES, 10 EGTA, 2 CsCl, 1 QX-314, 0.75 MK-801, pH 7.25. A K ${ }^{+}$-based intrapipette solution containing the following (in $\mathrm{mm}$ ): $130 \mathrm{~K}$-gluconate, $2 \mathrm{KCl}, 1 \mathrm{CaCl}_{2}, 4$ MgATP, 0.3 GTP, 8 phosphocreatine, 10 HEPES, 11 EGTA, pH 7.25, was used in some current-clamp recordings to measure membrane potential responses, resting membrane potential,and spike threshold. The pipette capacitance and whole-cell capacitance were compensated completely. The series resistance (25-50 M $\Omega$ ) was compensated by $50-60 \%$ (at 100 $\mu \mathrm{s}$ lag) to achieve an effective series resistance of 10-25 M $\Omega$. An $11 \mathrm{mV}$ junction potential was corrected. Signals were filtered at $2 \mathrm{kHz}$ for voltage-clamp recording, $5 \mathrm{kHz}$ for current-clamp recording, and sam- pled at $10 \mathrm{kHz}$. The evoked excitatory and inhibitory synaptic currents were resolved by clamping the cell at -70 and $0 \mathrm{mV}$, respectively. As discussed before, our blind whole-cell recording method highly biases sampling toward pyramidal neurons (Liu et al., 2009, 2010, 2011). For cell-attached recordings, glass electrodes containing the ACSF were used. A $100-250 \mathrm{M} \Omega$ seal was formed on the patched cell. The pipette capacitance was completely compensated. Spikes were recorded in voltageclamp mode, with a commend potential applied to achieve a zero baseline current. The spike signal was filtered at $10 \mathrm{kHz}$ and sampled at 20 $\mathrm{kHz}$. All neurons recorded in this study were located at a depth of 150 $400 \mu \mathrm{m}$ below the pia according to the microdrive reading, corresponding to layer $2 / 3$ and a small top part of layer 4 .

Visual stimulation. Software for data acquisition and visual stimulation was custom-developed in LabVIEW (National Instruments) and MATLAB (MathWorks) respectively. Visual stimuli were provided by a $34.5 \times 25.9 \mathrm{~cm}$ monitor (refresh rate $120 \mathrm{~Hz}$, mean luminance $\sim 41.1 \mathrm{~cd} / \mathrm{m}^{2}$ ) placed $0.25 \mathrm{~m}$ away from the right eye, which is equivalent to infinity (Liu et al., 2010). The center of monitor was placed at $45^{\circ}$ azimuth, $0^{\circ}$ elevation, and it covered $\pm 35^{\circ}$ horizontally and $\pm 27^{\circ}$ vertically of the mouse visual field, corresponding to the monocular zone of V1. To map the RF, either flashing bright ( 57.5 $\left.\mathrm{cd} / \mathrm{m}^{2}\right)$ and dark $\left(24.7 \mathrm{~cd} / \mathrm{m}^{2}\right)$ squares $\left(11 \times 11\right.$, each square was $\left.5^{\circ} \times 5^{\circ}\right)$ or flashing bars $\left(15\right.$ bars, each bar was $\left.4^{\circ} \times 60^{\circ}\right)$ of the preferred orientation were applied (over the gray background, contrast $=95 \%$ ) at different positions in a pseudorandom sequence. RFs were mapped for 5-10 repetitions. The stimulus duration was $200 \mathrm{~ms}$ and interstimulus interval was $240 \mathrm{~ms}$. To measure orientation tuning, drifting sinusoidal gratings $\left(2 \mathrm{~Hz}, 0.04 \mathrm{cycle} /{ }^{\circ}\right.$, contrast $95 \%$ ) or drifting bar ( $4^{\circ}$ width, $60^{\circ}$ length, $50 \%$ speed) of 12 directions $\left(30^{\circ}\right.$ step) were applied. For drifting gratings, stationary grating of one orientation was first presented on the full screen for $1.8 \mathrm{~s}$ before it drifted for $1.5 \mathrm{~s}$. The grating stopped drifting for $500 \mathrm{~ms}$ before another grating pattern appeared. Ideally, OS would be measured at the best spatial frequency. However, because we could only maintain a good recording within a limited time window and to apply all different combinations of orientation and spatial frequency took enormous time, we chose to measure OS at a spatial frequency of $0.04 \mathrm{cpd}$, as the largest fraction of mouse V1 cells prefers this spatial frequency and the average spatial frequency in layer $2 / 3$ is $0.04 \mathrm{cpd}$ (Niell and Stryker, 2008). It should be noted that this limitation does not affect our conclusions since measurements with single moving bars generated similar results (see below). For measuring response modulation (i.e., F1/F0 ratio), drifting sinusoidal gratings of the preferred direction (with temporal frequency of $2 \mathrm{~Hz}$ ) were presented for 10 cycles, at various spatial frequencies $\left(0.01,0.02,0.04,0.08,0.16\right.$, and $\left.0.32 \mathrm{cycle}^{\circ}\right)$. In total, $\sim 50-100$ cycles were collected. F1/F0 ratio was calculated at the preferred spatial frequency. Drifting bar was moved across the screen at an interstimulus interval of $3 \mathrm{~s}$. The 12 patterns were presented in a pseudorandom sequence, and were repeated 5-10 times. Spontaneous activity was recorded when a uniform gray background was presented.

Data analysis. Spikes were sorted offline. Spikes evoked by flashing stimuli were counted within a $70-270 \mathrm{~ms}$ time window after the stimulus onset. Spikes evoked by drifting stimuli were counted within a $70-1570$ ms window after the start of drifting. The spontaneous firing rate was subtracted from the stimulus-evoked spike rate. The cells included in the analysis should first show evoked spike responses to both flash stimuli and drifting bar/grating stimuli. Evoked responses are defined by firing rates exceeding the average spontaneous rate by three SDs of baseline fluctuations. Within this group of cells, cells that have well defined on and off subfields are included for analysis (81\%). Subfields are identified as spatially contiguous pixels with evoked responses. Firing rates of other pixels in the RF were set as zero. The cells analyzed in this study had one on and one off subfield.

To quantify the spatial overlap between two dimensional on and off subfields, we first fit the hard boundary of the subfield with an ellipse ( $\mathrm{Li}$ et al., 2013), and quantified the goodness of fitting by calculating the adjust $r$ square. Most of our fittings (91\% of all subfields) have a value larger than 0.9 , indicating that the ellipses did well in fitting the subfields. Then we calculated an overlap index (Liu et al., 2009; Li et al., 2013): OI = $\left(w_{1}+w_{2}-d\right) /\left(w_{1}+w_{2}+d\right)$, where OI is the overlap index, $d$ is the distance between the centers of two ellipses, and $w_{1}$ and $w_{2}$ are the halflength of the line segment connecting the centers of two ellipses and 
intercepted by each ellipse. $\mathrm{OI}=1$ gives a complete overlap, and $\mathrm{OI} \leq 0$ gives a complete separation. To calculate OI for One-dimensional (1-D) subfields, the hard boundary of the subfields were determined in a similar manner as in the two-dimensional RFs. The envelope for the peak response amplitudes (i.e., the spatial tuning curve) was generated using MATLAB software Envelope 1.1 (Sun et al., 2010), where $d$ was defined then as the distance between the peaks of on and off subfields, and $w_{1}$ and $w_{2}$ are the distance between the peak and the hard boundary of the subfield on the inner side. OI was calculated using the same equation as described above.

We also quantified the spatial overlap between on and off subfields using Pearson's correlation coefficient $\left(r_{\mathrm{RF}}\right)$ according to the following question (Priebe et al., 2004; Mata and Ringach, 2005; Liu et al., 2009):

$$
r_{R F}=\frac{\sum_{i=1}^{n}\left(R_{o n, i}-\bar{R}_{o n}\right)\left(R_{o f f, i}-\bar{R}_{o f f}\right)}{\sqrt{\sum_{i=1}^{n}\left(R_{o n, i}-\bar{R}_{o n}\right)^{2}\left(R_{o f f, i}-\bar{R}_{o f f}\right)^{2}}} .
$$

$R_{\mathrm{on}, i}$ and $R_{\mathrm{off}, i}$ and are individual responses to an on or off stimulus respectively. $\bar{R}_{\text {on }}$ and $\bar{R}_{\text {off }}$ are the mean on and off responses within the subfields.

To quantify the strength of OS, orientation selectivity index (OSI) and tuning width were calculated. The responses to two directions at each orientation were averaged to obtain the orientation tuning curve between 0 and $180^{\circ}$, which was then fit with a Gaussian function: $R(\theta)=A \times e^{-0.5 \times\left(\theta-\theta_{\text {pref }}\right)^{2} / \sigma^{2}}+B . \theta_{\text {pref }}$ is the preferred orientation determined by the vector sum of responses across orientations. OSI was quantified as follows: $\left(R_{\text {pref }}-R_{\text {orth }}\right) /\left(R_{\text {pref }}-R_{\text {orth }}\right)=A /(A+2 B)$, where $R_{\text {pref }}$ is the response level at the preferred orientation $\theta_{\text {pref }}$, and $R_{\text {orth }}$ is that at the angle of $\theta_{\text {pref }}+90^{\circ}$. Tuning width was defined as the half-width at half-height of the fitted Gaussian curve above the offset $B$.

To calculate the F1/F0 ratio, first the poststimulus spike time histogram (PSTH) was generated from all the cycles for responses over multiple repetitions. F1 response was calculated from the PSTH as the amplitude of the best-fitting sinusoid at the modulation frequency (Mata and Ringach, 2005). F0 response was the mean evoked spike rate during the drifting grating stimulus.

In current-clamp recordings, subthreshold membrane potential responses were analyzed after removing spikes with a median filter at $8 \mathrm{~ms}$ (Carandini and Ferster, 2000). Putative complex cells were identified by OI of spike response $\geq 0.33$ or OI of membrane potential response $>0.7$.

In voltage-clamp recordings, average excitatory and inhibitory response traces were first smoothed by averaging within a sliding $40 \mathrm{~ms}$ window (Li et al., 2012a,b). Excitatory and inhibitory synaptic conductance were derived according to the following equation (Wehr and $\mathrm{Za}$ dor, 2003; Liu et al., 2010):

$$
\begin{aligned}
I(t)=G_{r} \times\left(V_{\mathrm{m}}(t)-E_{r}\right)+G_{\mathrm{e}}(t) \times\left(V_{\mathrm{m}}(t)-E_{\mathrm{e}}\right) & +G_{\mathrm{i}}(t) \\
& \times\left(V_{\mathrm{m}}(t)-E_{\mathrm{i}}\right) .
\end{aligned}
$$

$I(t)$ is the amplitude of current at any time point, $G_{\mathrm{r}}$ and $E_{\mathrm{r}}$ are the resting leak conductance and resting membrane potential respectively, $G_{\mathrm{e}}$ and $G_{\mathrm{i}}$ are the excitatory and inhibitory synaptic conductance, respectively, $V_{\mathrm{m}}(t)$ is the membrane voltage, and $E_{\mathrm{e}}(0 \mathrm{mV})$ and $E_{\mathrm{i}}(-70 \mathrm{mV})$ are the reversal potentials. $V_{\mathrm{m}}(t)$ is corrected by $V_{\mathrm{m}}(t)=V_{\mathrm{h}}-R_{\mathrm{s}} \times I(t)$, where $R_{\mathrm{s}}$ was the effective series resistance and $V_{\mathrm{h}}$ is the applied holding voltage. Measurement of currents at two different voltages yielded a system of two equations that could be solved for $G_{\mathrm{e}}$ and $G_{\mathrm{i}}$ at any particular $t$. We used the bootstrapping method (bootstrap sampling $=1000$ times) to evaluate the variability of the derived conductance (Li et al., 2012a; Ma et al., 2013).

Neuron modeling. A conductance-based integrate-and-fire neuron model was used to simulate the membrane potential response (Liu et al., 2010; Li et al., 2012a,b, 2014):

$$
\begin{array}{r}
V_{m}(t+d t)=-\frac{d t}{C}\left[G_{e}(t)+\left(V_{m}(t)-E_{e}\right)+G_{i}(t)+\left(V_{m}(t)-E_{i}\right)\right. \\
\left.+G_{r}(t) \times\left(V_{m}(t)-E_{r}\right)\right]+V_{m}(t) .
\end{array}
$$

$V_{\mathrm{m}}(t)$ is the membrane potential at time $t, C$ is the whole-cell capacitance, $G_{\mathrm{r}}$ is the resting leak conductance, and $E_{\mathrm{r}}$ is the resting membrane potential $(-65 \mathrm{mV}) . E_{\mathrm{e}}$ and $E_{\mathrm{i}}$ were set at $0 \mathrm{mV}$ and $-70 \mathrm{mV}$, respectively. $G_{\mathrm{r}}$ was calculated based on the equation $G_{\mathrm{r}}=C \times G_{\mathrm{m}} / C_{\mathrm{m}}$, where $G_{\mathrm{m}}$, the specific membrane conductance is $2 \mathrm{e}-5 \mathrm{~S} / \mathrm{cm}^{2}$, and $C_{\mathrm{m}}$, the specific membrane capacitance is $1 \mathrm{e}-6 \mathrm{~F} / \mathrm{cm}^{2}$.

Synaptic conductance was simulated with a skew normal distribution function:

$$
\mathrm{f}(\mathrm{x})=\text { amplitude } \times \frac{2}{\omega} \times \varphi\left(\frac{x-\xi}{\omega}\right) \times \varnothing\left(\alpha\left(\frac{x-\xi}{\omega}\right)\right)+\text { baseline }
$$

where $\varphi$ and $\varnothing$ are the standard normal probability density function and the cumulative distribution function, respectively, and $\xi$ determines the location. The scale factor $(\omega)$ was set at $145 \mathrm{~ms}$ and the shape factor $(\alpha)$ at 1.5 for both excitatory and inhibitory conductance. Inhibition was set 25 ms delay relative to excitation ( $\mathrm{Li}$ et al., 2012a,b). Spike responses were simulated using a power law (Carandini and Ferster, 2000; Priebe and Ferster, 2008; Liu et al., 2011): $R\left(V_{m}\right)=k\left\lfloor V_{m}-V_{t h}\right]_{+}^{p} \cdot R$ is the firing rate, $k$ is the gain factor, $p$ is the exponent, and " + " indicates rectification.

\section{Results}

\section{OS of complex cells is weaker than simple cells}

To examine whether complex and simple cells in mouse V1 differ in the degree of orientation selectivity, we performed cellattached loose-patch recordings from excitatory neurons mainly in layer 2/3 (see Materials and Methods). We mapped the spiking visual $\mathrm{RF}$ of each recorded cell to determine the simple/complex cell type, and to reveal the relationship between OS and the RF structure. Figure $1 A$ shows the spatial patterns of spike responses of a cell to a set of bright (on) and dark (off) squares flashed for $200 \mathrm{~ms}$. The largely overlapped on and off response regions (i.e., on and off subfields) indicated that the cell was a complex cell. Figure $1 B$ shows the cell's responses to drifting sinusoidal gratings of different orientations and directions. The cell responded to gratings of all orientations, but responded maximally to gratings at a certain orientation angle. Figure $1 C, D$, shows the responses of another cell to flash and drifting stimuli. The on and off subfields of the cell were clearly segregated (Fig. 1C), indicating that the cell could be functionally identified as a simple cell. In response to drifting sinusoidal gratings, it exhibited apparently temporally modulated spiking responses which are sharply tuned for orientation (Fig. 1D).

We classified cell types based on the spatial overlap between on and off subfields, which was quantified with both an OI and a $r_{\mathrm{RF}}$ (see Materials and Methods). Consistent with our previous report (Liu et al., 2010), OIs of our recorded excitatory cells exhibited a bimodal distribution (Fig. 1E), indicating that they could be categorized into two classes. We used OI $=0.33$ as a criteria to separate complex cells from simple cells, following our previous study (Liu et al., 2009). In a total of 128 cells, 70 cells were classified as complex cells and 58 were classified as simple cells. These simple and complex cells slightly differ in depth distribution, in that complex cells were more frequently encountered than simple cells in shallower cortical locations $(p<0.01$, two-tailed $t$ test; Fig. $1 F$ ). To measure OS, drifting sinusoidal gratings were applied to 72 and drifting bars were applied to 27 of these cells. While all tested simple cells showed strong temporal response modulation to sinusoidal gratings, as reflected by a F1/F0 ratio larger than 1, only 16 of 41 complex cells exhibited a F1/F0 ratio smaller than 1 (Fig. $1 G$ ). These complex cells would then be classified as simple cells if based on F1/F0 ratio, another criterion for separating simple and complex cells (Skottun et al., 1991; Carandini et al., 1997; Anderson et al., 2000; Mata and 
A

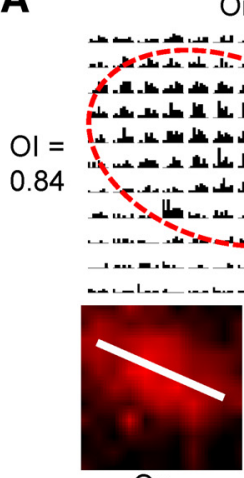

On

C

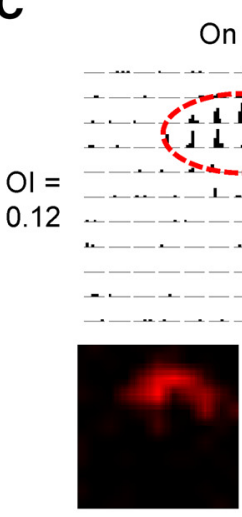

On Simple cell

Off
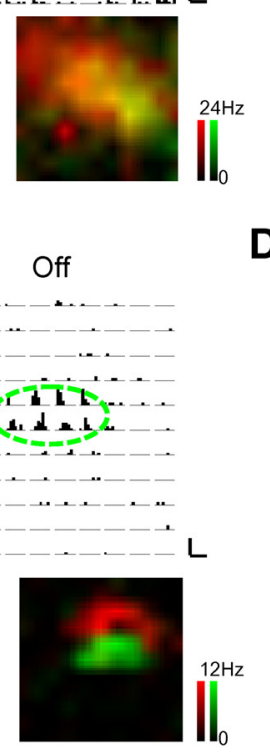

E

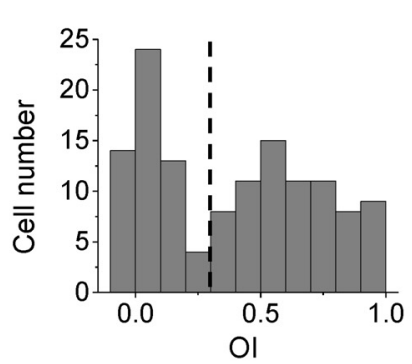

H

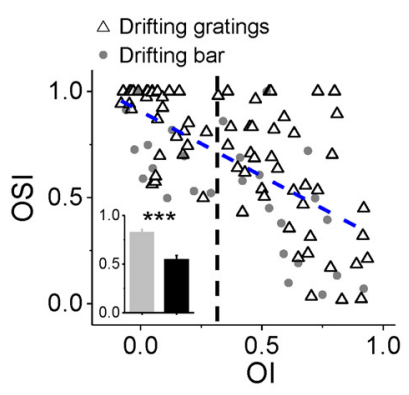

K

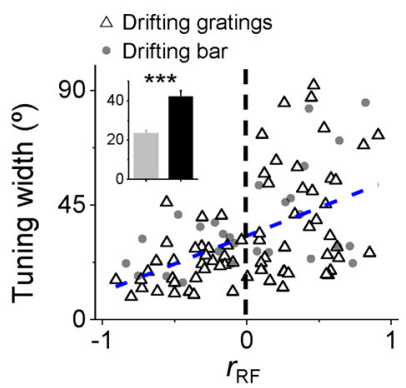

F

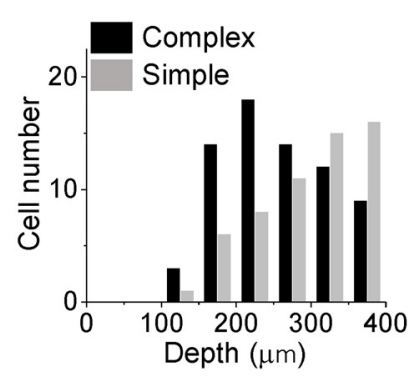

I

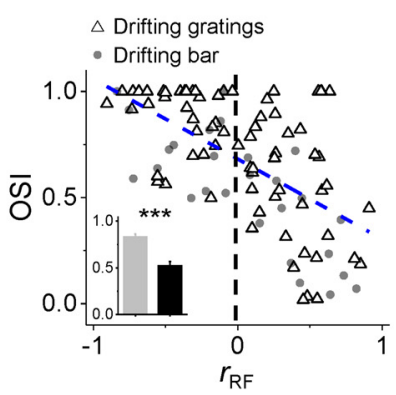

L

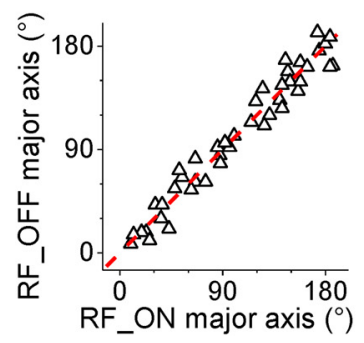

G

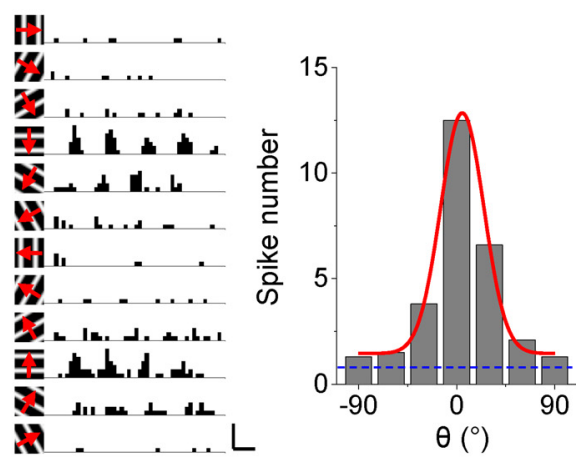

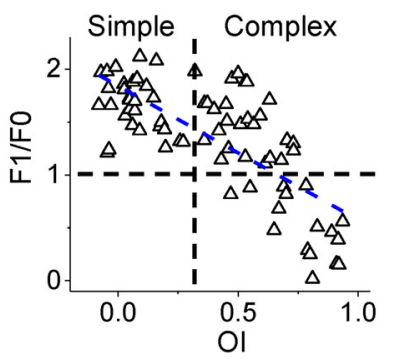

J

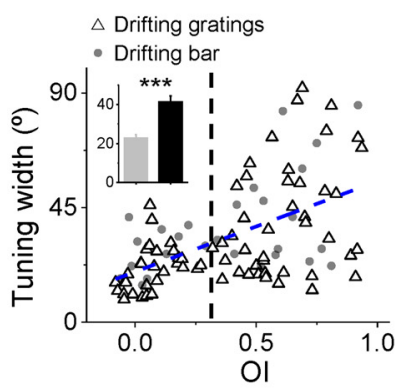

M

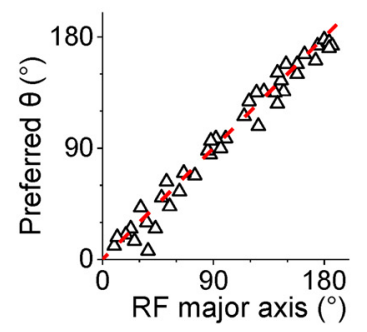


Ringach, 2005). Therefore, the cell classifications based on the two criteria do not strictly agree with each other. There was a negative correlation between F1/F0 ratio and OI (Fig. $1 G$; correlation coefficient $(r)=-0.74)$, reminiscent of a previous observation in macaque V1 (Mata and Ringach, 2005). We next quantified OS with both an OSI and orientation tuning width (see Materials and Methods), and examined the relationship between OS and the RF structure. We found that OSI was negatively correlated with both OI (Fig. $1 H$ ) and $r_{\mathrm{RF}}$ (Fig. 1I), whereas tuning width was positively correlated with OI and $r_{\mathrm{RF}}$ (Fig. $1 J, K$ ). Complex cells had significantly weaker OS (Fig. $1 \mathrm{H}, I$ ) and broader tuning widths than simple cells (Fig. $1 J, K$ ). Although most of the simple cells exhibited strong OS (with OSI $>0.5$ ), there were some complex cells that were not orientation selective (defined by OSI $<0.3$ ).

For 43 orientation-selective complex cells (with OSI $\geq 0.3$ ), we further examined the relationship between OS and the RF structure. We noticed that subfields of complex cells exhibited a slightly elongated shape (Fig. 1A). By fitting the subfield with an ellipse, we determined the major axis for the subfield (see Materials and Methods). The major axis for the on subfield was essentially identical to that for the off subfield (Fig. $1 L$ ). The RF major axis also agreed with the preferred orientation of the cell (Fig. $1 M)$. Based on these results, in the following intracellular recordings we applied flashing bars at the cell's preferred orientation to map the RF and determine the cell type. Furthermore, we did not find any significant difference in either evoked $(32.0 \pm 24.2 \mathrm{~Hz}$

\footnotetext{
Figure 1. Complex cells are less orientation selective than simple cells. A, Spike on/off subfields of an example complex cell examined by cell-attached recording. Top, Arrays of PSTHs for spike responses of the neuron to a set of bright (on) or dark (off) flash squares. PSTHs were arranged in 2-D space according to the locations of corresponding stimuli. Each pixel represents visual space of $5^{\circ}$. Red and green ovals depict the elliptic fitting of the on and off subfields, respectively. Spontaneous firing rate is $1.2 \mathrm{~Hz}$. Scale bars, $20 \mathrm{~Hz}$, $300 \mathrm{~ms}$. Bottom, Color maps for spike on (red) and off (green) responses. The brightness of color represents the average evoked firing rate. The maps were smoothed by bilinear interpolation. The white line depicts the RF major axis, defined by the long axis of the oval. $B$, Orientation tuning of the same cell. Left, PSTHs for its spike responses to drifting gratings at 12 directions. Red arrow indicates the drifting direction. Scale bars, $20 \mathrm{~Hz}, 250$ ms. Right, Orientation tuning curve of evoked spike numbers. The responses to gratings of opposite directions were averaged for each orientation. Red curve indicates the Gaussian fit. Blue dash line indicates the level of spontaneous spiking rate. $\boldsymbol{C}, \boldsymbol{D}$, An example simple cell. Data are displayed in a similar manner as in $\boldsymbol{A}$ and $\boldsymbol{B}$. Spontaneous firing rate is $0.6 \mathrm{~Hz}$. Scale bars: C, $21 \mathrm{~Hz}, 300 \mathrm{~ms} ; \boldsymbol{D}, 21 \mathrm{~Hz}, 300 \mathrm{~ms}$. $\boldsymbol{E}$, Distribution of overlap indices in the recorded cell population. The distribution is significantly bimodal ( $p<0.05$, Hartigan's dip test). Dash line marks $0 \mathrm{I}=0.33$ (which separates simple from complex cells). $\boldsymbol{F}$, Depth distribution of the recorded cells. $\mathbf{G}$, Plot of F1/F0 ratio against 0 l. Blue dash line is the best-fit linear regression line. Correlation coefficient $r=-0.74$. Black dash lines mark $0 \mathrm{I}=0.33$ and $\mathrm{F} 1 / \mathrm{FO}=1$, respectively. $\boldsymbol{H}$, Plot of $\mathrm{OSI}$ against $0 \mathrm{I}$. OSI was measured from responses to either drifting gratings (open triangle) or drifting bars (gray dots). Blue dash line is the best-fit linear regression line $(r=-0.63)$. Black dash line marks $0 \mathrm{O}=0.33$. Inset, Comparison of mean OSIs of complex (black, $n=57$ ) and simple (gray, $n=42$ ) cells defined by 0 I values. ${ }^{* * *} p<0.001$, two-tailed $t$ test. $I$, Plot of 0 SI against $r_{\text {RF }}$ measured between on and off subregions $(r=-0.59)$. Black dash line marks $r_{\mathrm{RF}}=0$, which separates complex from simple cells. Inset, Comparison of mean OSIs of complex $(n=54)$ and simple $(n=45)$ cells defined by $r_{\text {RF }}$ values. ${ }^{* * *} p<0.001$, two-tailed $t$ test. J, Plot of tuning width against $0 \mathrm{Ol}(r=0.54)$. Inset, Comparison of mean tuning widths of complex and simple cells defined by 0 l values. ${ }^{* *} p<0.001$, two-tailed $t$ test. $\boldsymbol{K}$, Plot of tuning width against $r_{\mathrm{RF}}(r=0.51)$. Inset, Comparison of mean tuning widths of complex and simple cells defined by $r_{\mathrm{RF}}$ values. ${ }^{* * *} p<0.001$, two-tailed $t$ test. $L$, Plot of angle of the major axis of on subfield versus that of off subfield for complex cells $(n=43)$. Red dash line is the identity line. Note that only complex cells with $0 \mathrm{SI} \geq 0.3$ were selected. $\boldsymbol{M}$, Plot of angle of the preferred orientation (measured with drifting gratings or bars) and that of RF major axis (measured with flash squares). Red dash line is the identity line.
}

for simple cells; $37.2 \pm 33.4 \mathrm{~Hz}$ for complex cells; $p=0.80$, two-tailed $t$ test $)$ or spontaneous firing rate $(2.3 \pm 2.8 \mathrm{~Hz}$ for simple cells; $2.4 \pm 4.0 \mathrm{~Hz}$ for complex cells; $p=0.96$, two-tailed $t$ test) between simple and complex cells. This indicates that complex and simple cells in our study have similar signal-to-noise ratios in their responses.

\section{Subthreshold membrane potential responses of complex cells} We next performed in vivo whole-cell recordings with a $\mathrm{K}^{+}$gluconate based internal solution to examine OS of subthreshold membrane potential $\left(V_{\mathrm{m}}\right)$ responses. We first measured the orientation tuning of $V_{\mathrm{m}}$ responses under current-clamp by applying drifting sinusoidal gratings at 12 directions. The spike responses of the cell were also recorded at the same time. Onedimensional RF structure was then measured by applying flashing bars of preferred orientation at different locations, and the cell type was determined based on the overlap between spike on and off responses in the 1-D space. The example cell in Figure $2 A$ was identified as a complex cell, based on its largely overlapped on and off spike subfields. The cell's spiking response was moderately orientation tuned, whereas its subthreshold $V_{\mathrm{m}}$ response was much more broadly tuned (Fig. $2 B, 2 C$ ). Nonetheless, the spike and $V_{\mathrm{m}}$ responses exhibited a similar preferred orientation (Fig. 2C). An example simple cell was displayed in a similar manner (Fig. $2 D-F$ ).

In 49 similarly recorded cells, 24 were identified as complex cells (spike OI $>0.33$ ) and 25 as simple cells (spike OI $<0.33$; Fig. $2 G$ ). We found a strong positive correlation between OI values calculated from spike and $\mathrm{V}_{\mathrm{m}}$ responses (Fig. 2G, $r=$ 0.91 ), indicating that OI calculated from the $V_{\mathrm{m}}$ response can be used as a measure to predict simple or complex cell type. Here we set OI_ $V_{\mathrm{m}}=0.7$ as a separation point between simple and complex cells (Fig. 2G). As for orientation tuning, for both the complex and simple cells, OSI calculated from the spike response was much larger than that from the $V_{\mathrm{m}}$ response, consistent with the notion that the spike thresholding mechanism in general greatly enhances neuronal selectivity (Carandini and Ferster, 2000; Priebe and Ferster, 2008; Liu et al., 2011). In addition, for both the complex and simple cells, there was a strong positive correlation between OSIs calculated from spike and subthreshold $V_{\mathrm{m}}$ responses $(r=0.82$ for complex cells; $r=0.83$ for simple cells; $r=0.81$ for all the cells; Fig. $2 H$ ), suggesting that OSI_ $V_{\mathrm{m}}$ can be used as a measure to predict the degree of OS of the cell. If OSI_spike $=0.3$ is set as a criterion for defining orientation selective neurons, it would correspond approximately to OSI $V_{\mathrm{m}}=0.06$. The latter was then used as a criterion in the following intracellular recordings to identify putative orientation selective cells. Similar as the loose-patch recording results, the complex and simple cell groups differed significantly in the mean value of OSI_spike ( $p<0.001$, two-tailed $t$ test), and a small subset of the complex cells were not orientation selective (Fig. $2 H$ ). For the orientation selective complex cells, their spike and subthreshold $V_{\mathrm{m}}$ responses displayed a similar preferred orientation (Fig. 2I), similar as simple cells (Liu et al., 2011). The $V_{\mathrm{m}}$ responses of complex cells were more broadly tuned than those of simple cells, although there was a large overlap between the distributions of OSI_ $V_{\mathrm{m}}$ values of these two cell groups (Fig. 2J; $p<0.05, t$ test). To determine whether the transformation from membrane potential to spike would contribute to the differential OS between complex and simple cells, we fit the relationship between membrane potential and spike responses with a power-law function and calculated the 
A

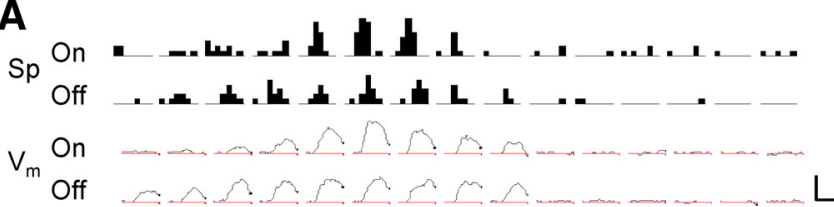

B

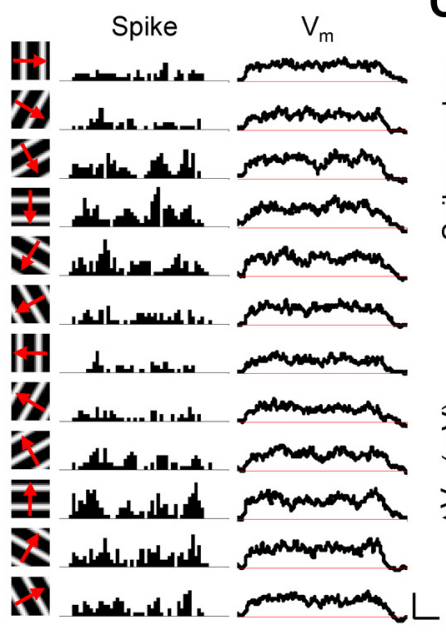

C
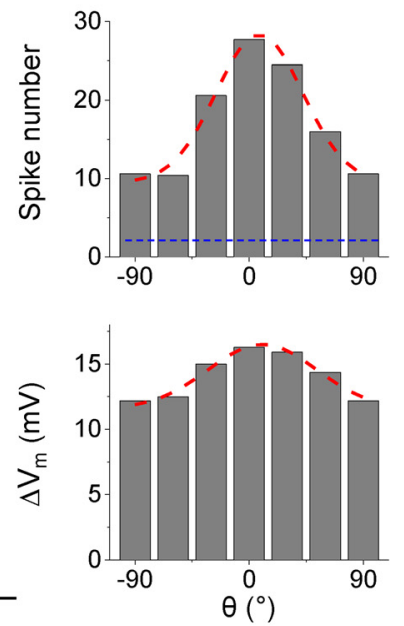

G

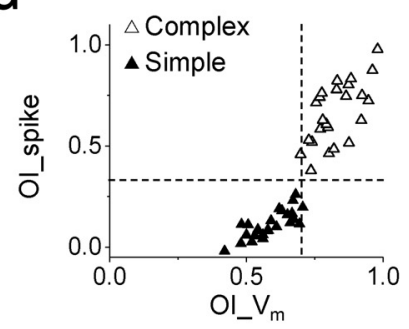

K

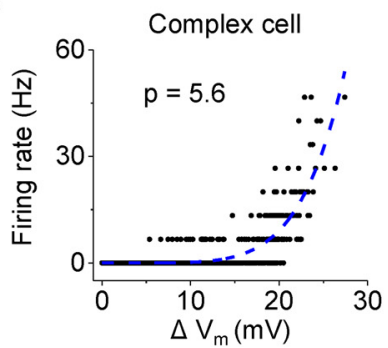

H

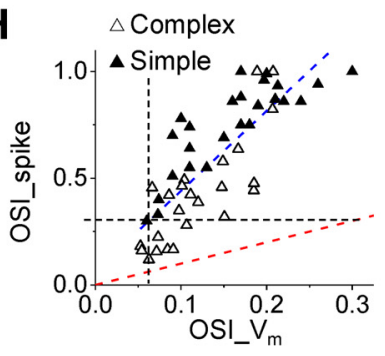

L

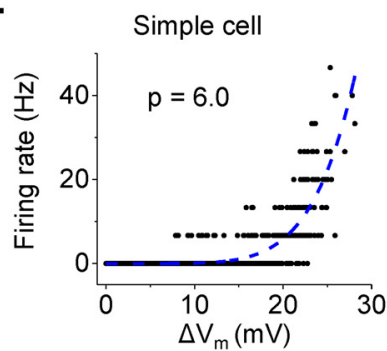

D

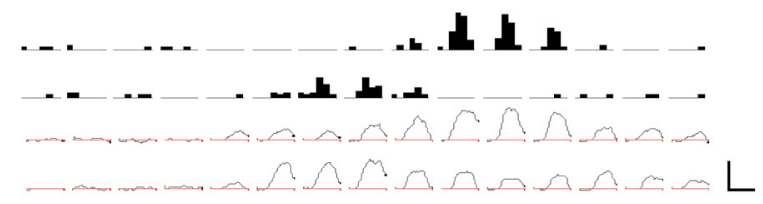

E
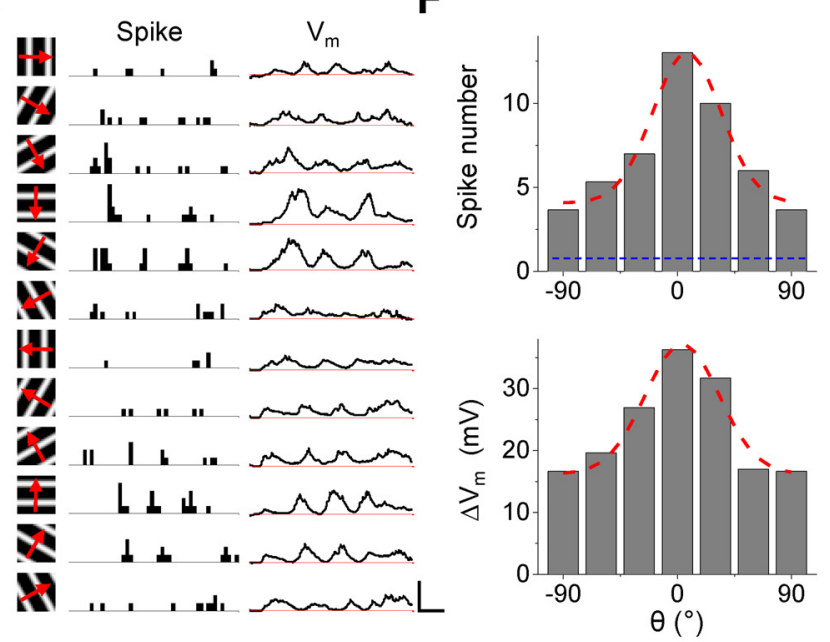

I

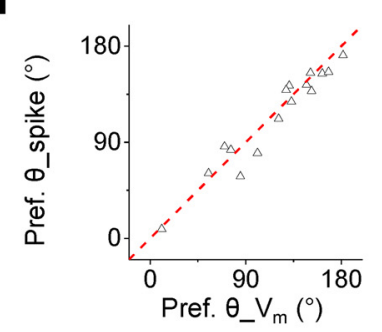

J

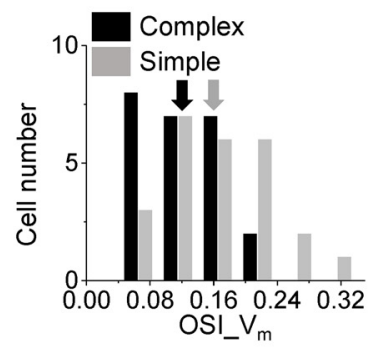

M

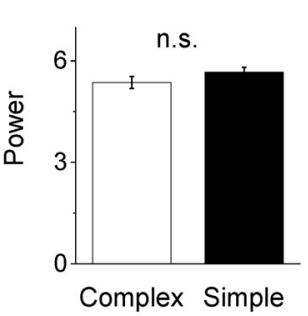

$\mathbf{N}$

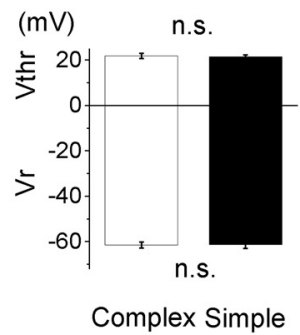

Figure 2. Orientation tuning of subthreshold membrane potential responses in complex and simple cells. A, PSTHs for spike responses (Sp, top) and average subthreshold membrane potential responses $\left(V_{m}\right.$, bottom; after filtering out spikes) to 15 flash bars at different locations, plotted for an example complex cell examined by whole-cell current-clamp recording. Red dash lines indicate the level of resting membrane potential. Scale bars, $30 \mathrm{~Hz}$ (spike)/22 $\mathrm{mV}\left(V_{\mathrm{m}}\right), 300 \mathrm{~ms}$. B, PSTHs for spike responses (left) and average subthreshold $V_{\mathrm{m}}$ responses (right) to drifting gratings, plotted for the same cell in $A$. Scale bars, $40 \mathrm{~Hz} / 21 \mathrm{mV}, 200 \mathrm{~ms}$. C, Orientation tuning curves of spike (top) and $V_{\mathrm{m}}$ (bottom) responses for the same cell. Red dash curves depict Gaussian fits. $V_{\mathrm{m}}$ response was measured as the peak depolarization relative to the resting membrane potential in the cycle-averaged waveform. $\boldsymbol{D}-\boldsymbol{F}$, An example simple cell. Data are displayed in a similar manner as in $\boldsymbol{A}$ - $\boldsymbol{C}$. Scale bars: $\boldsymbol{D}, 40 \mathrm{~Hz} / 24 \mathrm{mV}, 300 \mathrm{~ms} ; \boldsymbol{E}, 60 \mathrm{~Hz} / 36 \mathrm{mV}, 200 \mathrm{~ms}$. $\boldsymbol{G}$, Plot of 01 measured from spiking responses versus 01 measured from $V_{\mathrm{m}}$ responses. Horizontal dash line marks $01 \_s p i k e=0.33$. Vertical dash line marks $01 \_V_{m}=0.7$, which separates complex from simple cells. $\boldsymbol{H}$, Plot of OSI measured from spike responses versus OSI measured from $V_{\mathrm{m}}$ responses. Red dash line is the identity line. Blue dash line is the best-fit linear regression line $(r=0.81)$. Horizontal dash line marks OSI_spike $=0.3$. Vertical dash line marks $0 S I \_V_{\mathrm{m}}=0.06$, which separates orientation selective from nonselective neurons. I, Plot of angle of the preferred orientation measured from spike responses versus that from $V_{m}$ responses, for complex cells with $0 S I$ Spike $\geq 0.3$ only. Red dash line is the identity line.J, Distribution 0 SIs measured from $V_{\mathrm{m}}$ responses. There is a significant difference between simple and complex cells. $p<0.05$, two-tailed $t$ test. $\boldsymbol{K}$, Plot of firing rate versus $V_{\mathrm{m}}$ response, fit with a power-law function, for an example complex cell. The power value is indicated. $\boldsymbol{L}$, Plot of firing rate versus $V_{\mathrm{m}}$ response for an example simple cell. $\boldsymbol{M}$, Comparison of powers between complex $(n=24)$ and simple $(n=25)$ cells. $p=0.28$, two tailed $t$ test. Bar $=$ SEM. $\boldsymbol{N}$, Comparison of spike threshold and resting membrane potential between complex $(n=24)$ and simple $(n=$ 25) cells. $p=0.43,0.47$, respectively, two tailed $t$ test. Error bar indicates SEM.

power (Priebe et al., 2004; Priebe and Ferster, 2008). As shown by the example complex and simple cells, the data were well described by the function (Fig. $2 K, L$ ). No significant difference was found for the power between complex and simple cells $(5.36 \pm 0.86$ for complex; $5.66 \pm 0.71$ for simple; $p=$
0.28, two-tailed $t$ test Fig. 2M). Because we did not find significant difference in the level of spike threshold $(21.8 \pm 5.8$ $\mathrm{mV}$ for complex; $21.4 \pm 3.9 \mathrm{mV}$ for simple; $p=0.43$, twotailed $t$ test) or that of resting membrane potential ( $-61.5 \pm$ $6.2 \mathrm{mV}$ for complex; $-61.2 \pm 8.9 \mathrm{mV}$ for simple; $p=0.47$, 
A

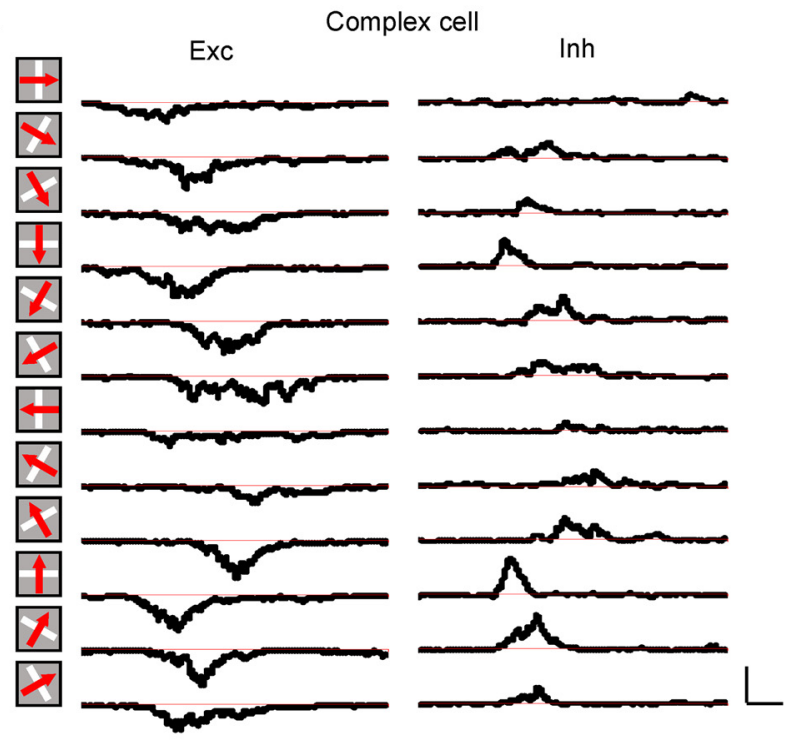

B

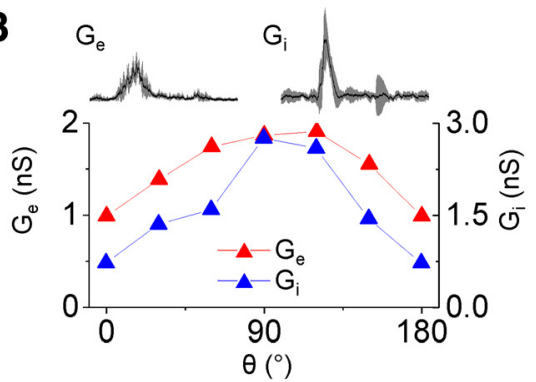

C

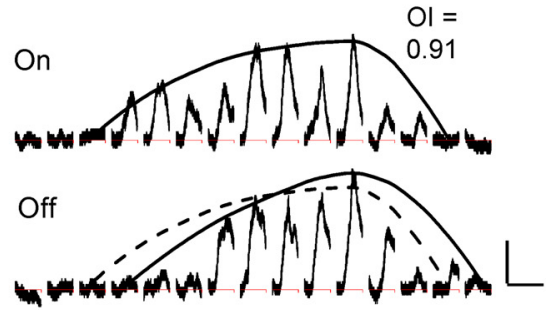

D

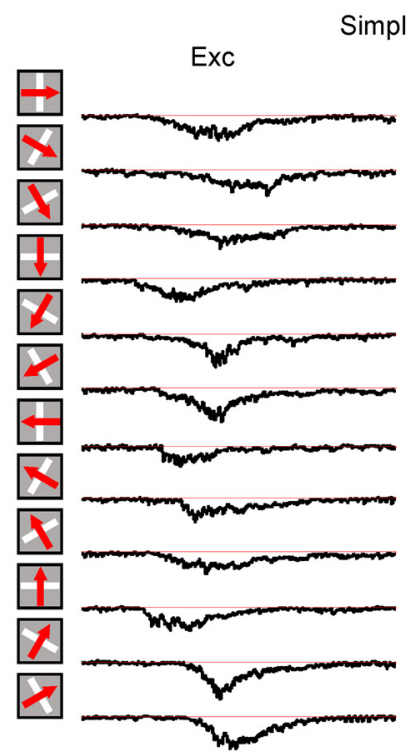

Simple cell

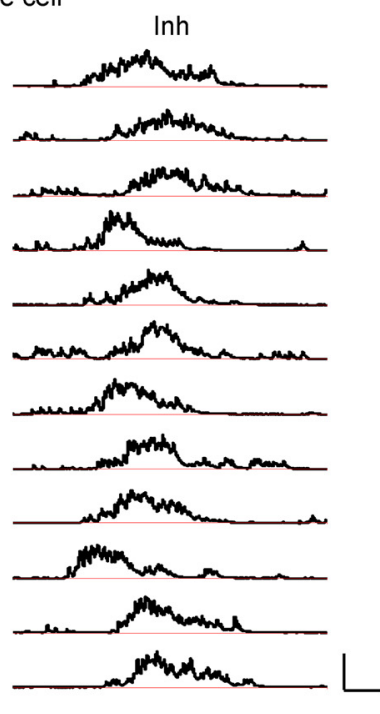

E

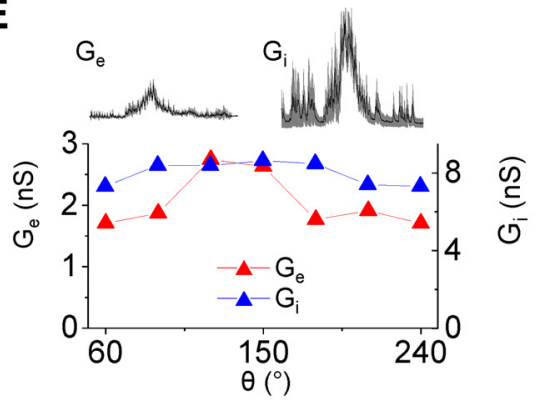

$\mathbf{F}$
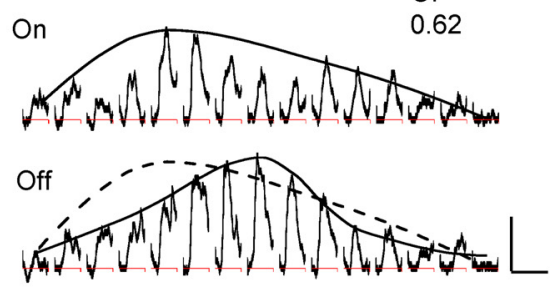

Figure 3. Synaptic inputs to complex and simple cells. A, Average excitatory (Exc) and inhibitory (Inh) currents in an example complex cell evoked by drifting bars at 12 directions ( 5 trials). Red arrow indicates the moving direction. Scale, $150 \mathrm{pA}$ (Exc)/210 pA (Inh), $300 \mathrm{~ms}$. B, Orientation tuning curves for peak evoked excitatory (red) and inhibitory (blue) conductance for the same cell shown in $\boldsymbol{A}$. Top, Inset, Traces of derived synaptic conductance at the preferred direction. Shading indicates $95 \%$ confidence level. $C$, 1-D RF of $V_{m}$ responses (recorded in current-clamp) to flashing bars of preferred orientation, for the same cell in $A$. Each bar is $4^{\circ}$ in width. Dash and solid curves in the bottom depict the spatial tuning (i.e., the envelope of peak response amplitudes) of on and off responses respectively. Scale, $8 \mathrm{mV}, 200 \mathrm{~ms}$. Ol value is indicated. $\boldsymbol{D}-\boldsymbol{F}$, An example simple cell. Data are presented in the same as in $\boldsymbol{A}-\boldsymbol{C}$. Scales: $\boldsymbol{D}, 200 \mathrm{pA}(\mathrm{Exc}) / 600 \mathrm{pA}(\mathrm{Inh}), 300 \mathrm{~ms} ; \boldsymbol{F}, 10 \mathrm{mV}$, $200 \mathrm{~ms}$.

two-tailed $t$ test; Fig. $2 N$ ), the differential degree of OS between complex and simple cells could be primarily attributed to the differential tuning of their $V_{\mathrm{m}}$ responses.

Inhibition is more narrowly tuned than excitation in complex cells

We further dissected the synaptic mechanisms underlying the weaker orientation tuning of complex cells by performing wholecell voltage-clamp recordings with a cesium-based internal solution (see Materials and Methods). Before switching recording to voltage-clamp, we mapped orientation tuning of $V_{\mathrm{m}}$ response with drifting bars as well as on and off subfields with flashing bars of the preferred orientation (see Materials and Methods). OI_ $V_{\mathrm{m}}$ $<0.7$ was used as a criterion to identify putative complex cells
(Fig. 2G) and only cells with OSI_ $V_{\mathrm{m}}>0.06$ (putative orientation selective neurons, 14 of 16 recorded neurons) were further analyzed. Excitatory and inhibitory synaptic currents evoked by drifting bars were then recorded under voltage-clamp, by clamping the cell's membrane potential at -70 and $0 \mathrm{mV}$, respectively. The cell shown in Figure 3, $A-C$, was a putative complex cell, since it displayed largely overlapped on and off subfields (Fig. $3 C$ ). Its $V_{\mathrm{m}}$ responses (traces not shown) exhibited an OSI of 0.18 , indicating that it was a presumptive orientation selective neuron. We calculated evoked synaptic conductance (Fig. $3 B$, top inset) from the recorded currents (Fig. $3 A$ ), and found that the inhibitory input displayed narrower orientation tuning than the excitatory input (Fig. 3B) in this complex cell, as measured by the peak evoked synaptic conductance. On the other hand, in a putative 
simple cell, we found that the inhibitory input was more broadly tuned than the excitatory input (Fig. 3D-F).

The average normalized tuning curves for a total of 14 similarly identified orientation selective complex cells showed that inhibition was more narrowly tuned than excitation (Fig. 4A), with a narrower tuning width compared with excitation (Fig. $4 A$, inset). In contrast, in a total of $12 \mathrm{sim}$ ple cells, inhibition was more broadly tuned than excitation (Fig. 4B), with a broader tuning width compared with excitation (Fig. $4 B$, inset). These trends were observed in all individual complex and simple cells, as demonstrated by the plot of ratio of OSI for inhibition over that for excitation in the same cell versus OI measured from $V_{\mathrm{m}}$ responses (Fig. 4C). For complex cells, the mean OSI \pm SD was $0.23 \pm 0.08$ for excitation and $0.33 \pm 0.11$ for inhibition (Fig. $4 D ; p<0.001$, twotailed paired $t$ test). For simple cells, the mean OSI was $0.26 \pm 0.09$ for excitation and $0.12 \pm 0.10$ for inhibition (Fig. $4 D$; $p<0.001$, two-tailed paired $t$ test). We did not find a significant difference in the tuning level of excitation between complex and simple cells (Fig. $4 D ; p=0.37$, two-tailed $t$ test), as the normalized amplitude of excitation at the orthogonal orientation was $0.62 \pm 0.14$ for simple cells and $0.70 \pm 0.22$ for complex cells (Fig. $4 A, B ; p=0.33$, twotailed $t$ test). However, there was a significant difference in the tuning level of inhibition between these two cell classes (Fig. $4 D ; p<0.001$, two-tailed $t$ test). In addition, for both orientation selective complex and simple cells, we found that inhibition and excitation had essentially identical orientation preferences (Fig. 4E), an observation in agreement with some measurements in the cat (Anderson et al., 2000; Mariño et al., 2005). Specifically, the excitation/inhibition (E/I) ratio at the orthogonal orientation was significantly larger in complex than simple cells $(p<0.001$, two-tailed $t$ test), whereas that at the preferred orientation did not differ between the two cell classes ( $p=0.36$, two-tailed $t$ test; Fig. $4 F$ ).

\section{Narrowly tuned inhibition contributes to the weaker OS of complex cells}

We have shown that a prominent difference between complex and simple cells lies in the relative tuning relationship between excitation and inhibition. In complex cells, E/I ratio was higher for the orthogonal orientation than the preferred orientation, while in simple cells $\mathrm{E} / \mathrm{I}$ ratio was lower for the orthogonal orientation than the preferred (Fig. $4 F$ ). The relatively weaker inhibition at the orthogonal orientation may reduce the effectiveness of inhibitory sharpening of orientation tuning of output responses. Consistent with this idea, we found that the $V_{\mathrm{m}}$ response in complex cells showed significantly weaker orientation tuning than
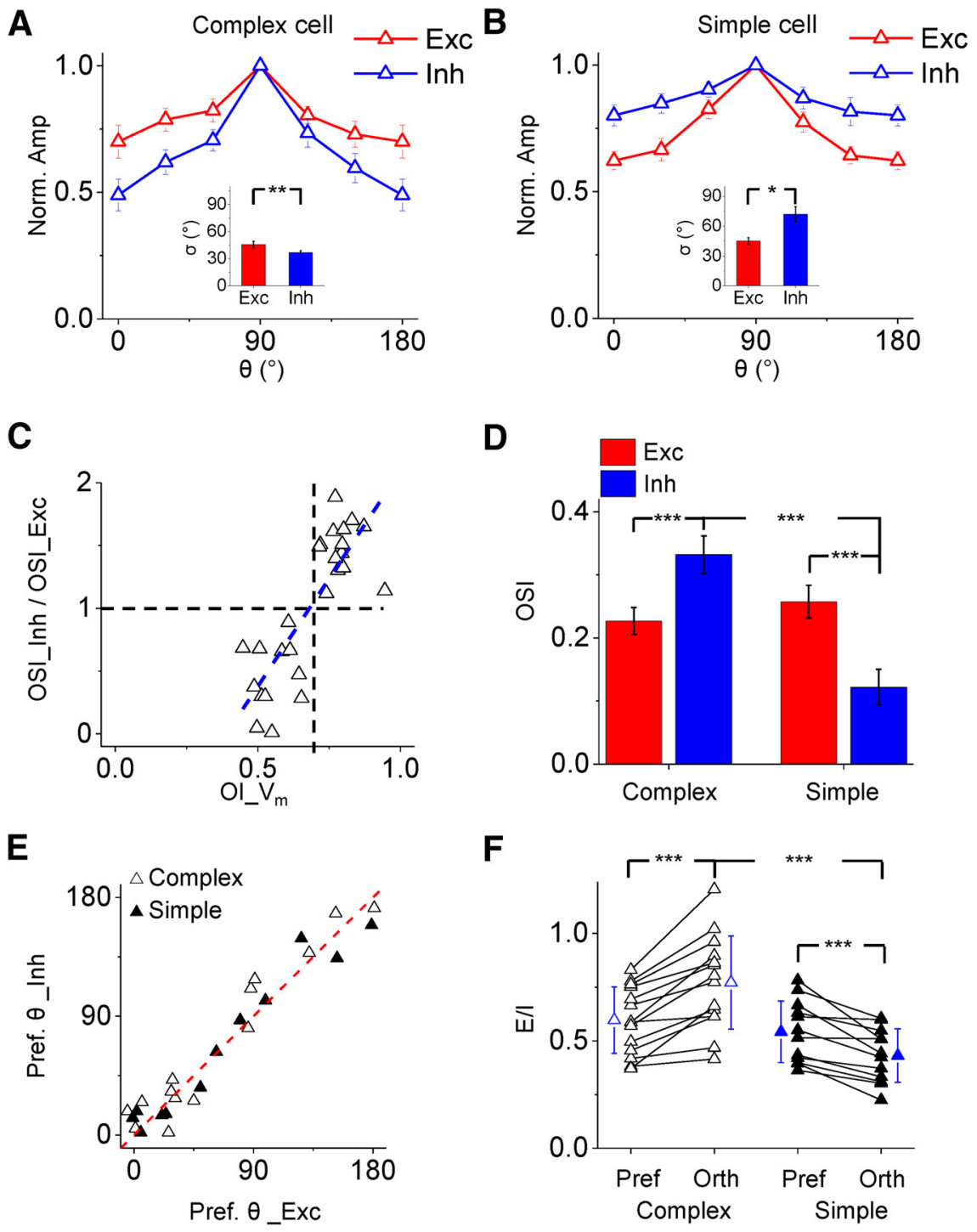

Figure 4. Differential orientation tuning of excitatory and inhibitory inputs in complex and simple cells. $\boldsymbol{A}$, Average normalized orientation tuning curves for excitatory (red) and inhibitory (blue) inputs to complex cells ( $n=14)$. Error bar indicates SD. Inset, $B$, Average normalized orientation tuning curves for excitatory and inhibitory inputs to simple cells $(n=12)$. Inset, Comparison of ing widths. ${ }^{*} p<0.05$, two-tailed paired $t$ test. C, Ratio of OSI of inhibitory input over that of the excitatory input in the same marks OSI_inh $=0$ SI_exc. Vertical dash line marks 0 I $V_{m}=0.7$, which separates complex from simple cells. $D$, Average 0SIs mean \pm SD. ${ }^{* * *} p<0.001$, two-tailed paired $t$ test or $t$ test. Data points for the same cell are connected by a line.

their excitatory input $\left(\mathrm{OSI}=0.15 \pm 0.08\right.$ for $V_{\mathrm{m}}$ vs $0.20 \pm 0.11$ for excitation, $p<0.01$, two-tailed paired $t$ test; Fig. $5 \mathrm{~A}$ ), whereas in simple cells OSI of $\mathrm{V}_{\mathrm{m}}$ response was similar to that of excitation (OSI $=0.25 \pm 0.10$ for $V_{\mathrm{m}}$ vs $0.26 \pm 0.09$ for excitation, $p=0.62$, two-tailed paired $t$ test; Fig. 5A).

To have a more thorough understanding of how the relative tuning relationship between excitation and inhibition shapes OS of output responses, we performed simulations in a conductance-based neuron model (see Materials and Methods). Because we did not find significant differences in synaptic strengths between simple and complex cells at the preferred orientation (Fig. 5B), we fixed the amplitudes of excitation and inhibition at the preferred orientation, as well as the tuning profile 

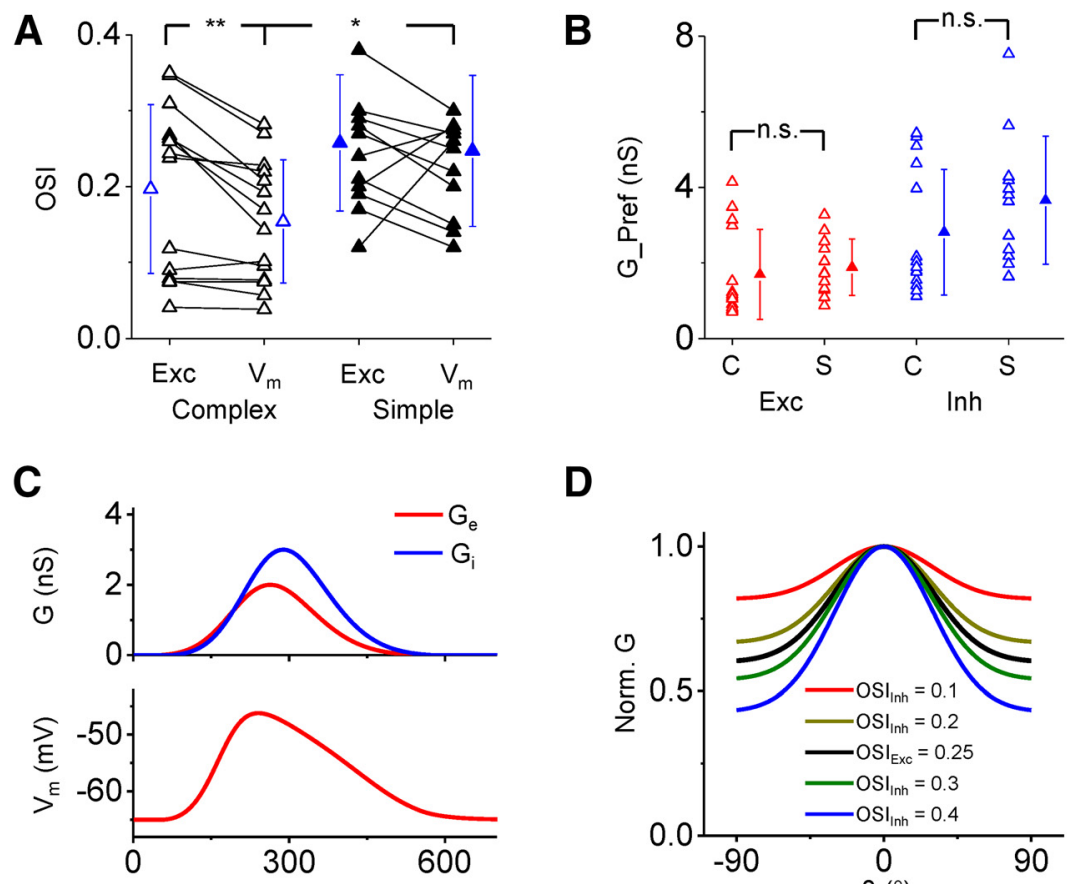

D
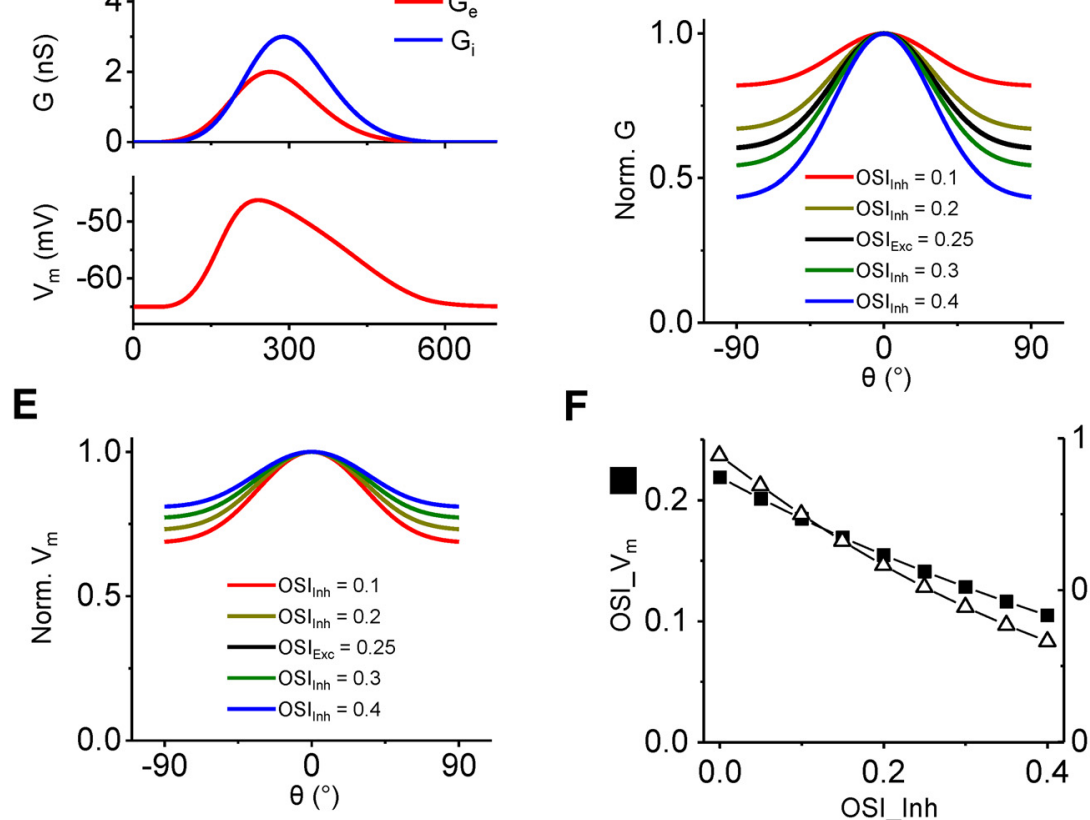

$\mathbf{F}$

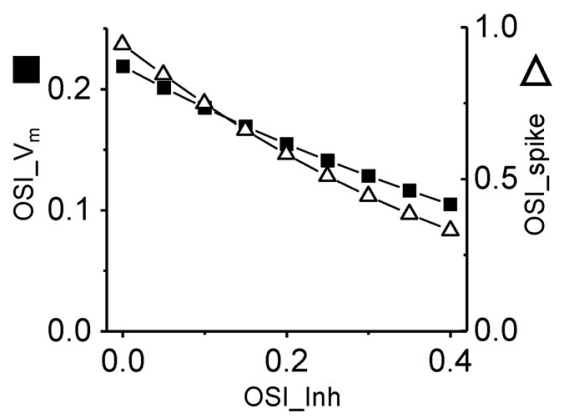

Figure 5. Inhibition can determine the differential orientation tuning in complex and simple cells. $\boldsymbol{A}$, Comparison of OSIs of excitatory input and $V_{\mathrm{m}}$ response for complex and simple cells. Data points for the same cell are connected by a line. ${ }^{* *} p<0.01$, two-tailed paired $t$ test. ${ }^{*} p<0.05$, two-tailed $t$ test. $\boldsymbol{B}$, Comparison of peak evoked synaptic conductance at the preferred orientation between complex (C) and simple $(S)$ cells. There is no significant difference between $($ and $S$ for excitation or inhibition ( $p=0.63,0.21$, respectively, two-tailed $t$ test). C, Temporal profiles of simulated evoked excitatory (red) and inhibitory (blue) synaptic conductanc (top), and the derived $V_{m}$ response using the neuron model (bottom). The resting membrane potential was set at $-65 \mathrm{mV}$. D, Simulated orientation tuning curves for synaptic conductance. Black curve is for excitation (fixed at OSI $=0.25$ ). Colored curves are for inhibition at various 0 SIs. $E$, Normalized tuning curves for derived $V_{m}$ responses resulting from integration of excitation and inhibition of different tuning relationships (colors correspond to different conditions in $\boldsymbol{D}$ ). $\boldsymbol{F}$, OSIs of $V_{\mathrm{m}}$ (solid square) and spike (open triangle) responses at varying degrees of inhibitory tuning.

of excitation, while allowing the tuning profile of inhibition to vary. We simulated excitatory and inhibitory conductance evoked by the preferred directional bar using mathematical functions fitting the average experimental data (Fig. $5 C$, top). By integrating excitation and inhibition in the neuron model, the expected $V_{\mathrm{m}}$ response could be derived (Fig. $5 C$, bottom). The amplitudes of excitation and inhibition at each of other stimulus orientations were than scaled according to their respective orientation tuning profiles. The OSI for excitation was set at 0.25 (Fig. $5 D$, black curve). The OSI for inhibition varied from 0.1 to 0.4 at a step of 0.1 (Fig. 5D, color curves). The normalized tuning curves of $V_{\mathrm{m}}$ responses derived from these simulated conductance showed that as the inhibitory tuning became more and more narrowed, the tuning of $V_{\mathrm{m}}$ response became broader and broader (Fig. $5 E$ ). As OSI of inhibition increased from 0 (i.e., untuned) to 0.4 , OSI of $V_{\mathrm{m}}$ response reduced from 0.22 to 0.10 (Fig. 5F, solid square). This would result in an even faster de- crease in OSI of spike response (Fig. $5 F$, open triangle), as demonstrated by our simulated spiking responses (see Materials and Methods). These modeling results indicate that inhibition being more narrowly tuned than excitation can largely contribute to the weaker OS of complex cells relative to simple cells.

\section{Synaptic RFs of complex cells}

Previous studies have shown that OS of simple cells can be predicted, at least partially, from their RF organization (Jones and Palmer, 1987; Gardner et al., 1999; Lampl et al., 2001; Liu et al., 2011). OS of complex cells however is generally thought not correlated with their RF architecture. In our loose-patch recording data, we noticed that the spike subfields were often slightly elongated, and the axis for the elongation was in accordance with the preferred orientation of the cell (Fig. $1 M)$. Here, we further looked into this issue at the synaptic input level, by mapping 2-D on and off subfields of excitatory and inhibitory inputs (Fig. 6A,B). Consistent with the spiking response results, synaptic subfields (both excitatory and inhibitory) in complex cells appeared elongated (Fig. $6 A$ ). To measure the degree of elongation, we fit the synaptic subfields with ellipses (see Materials and Methods). An aspect ratio, defined as the ratio of the subfield long axis over the short axis, was calculated for the subfield of a given contrast (on or off). As shown by the plot of aspect ratio for inhibitory subfield versus that for its excitatory counterpart, all of the subfields had an aspect ratio well over 1 (Fig. $6 C)$, indicating that they were indeed elongated. In addition, the majority of data points were above the identity line, indicating that in individual complex cells, the inhibitory subfield tended to be more elongated than the corresponding excitatory subfield (Fig. $6 C$; $p<0.01$, twotailed paired $t$ test). Conversely, simple cells tended to show a more elongated excitatory than inhibitory subfield (Fig. $6 D ; p<$ 0.05 , two-tailed paired $t$ test). Comparison of distributions of aspect ratios (Fig. $6 E$ ) indicated that inhibitory subfields as a population were significantly more elongated in complex than simple cells ( $p<0.001$, two-tailed $t$ test), whereas excitatory subfields were only slightly more elongated in complex than simple cells ( $p<0.05$, two-tailed $t$ test). For individual cells, the ratio between aspect ratios of inhibitory and excitatory subfields was significantly $>1$ in complex cells $(p<0.001$, two-tailed $t$ test), and also was significantly higher in complex than simple cells $(p<0.001$, two-tailed $t$ test; Fig. $6 F)$. These results demonstrate that in complex cells, the inhibitory subfield tended to be more elongated than the excitatory subfield responding to the same stimulus contrast, whereas in simple cells inhibitory subfield tended to be slightly less elongated. These observations correlate well with the finding that orientation tuning of inhibition is nar- 
rower than excitation in complex cells, and that it is narrower in complex than simple cells.

\section{Discussion}

In this study, we have measured the orientation tuning of complex cells in mostly the superficial layers of mouse V1 at three different levels: spiking response, membrane potential response, and synaptic conductance. We found that complex cells are less selectively tuned than simple cells at both the spiking and membrane potential response levels. By dissecting excitatory and inhibitory synaptic inputs with voltage-clamp recordings, we found that the difference in the degree of OS between complex and simple cells can be primarily attributed to an inhibitory synaptic mechanism: although the selectivity level of excitation is similar between complex and simple cells, inhibition is more selectively tuned in complex than simple cells. The two types of neuron thus differ in the tuning relationship between excitation and inhibition: in complex cells inhibition is more narrowly tuned than excitation, whereas in simple cells inhibition is more broadly tuned than excitation. Our modeling results further suggested that the differential excitatory/inhibitory tuning relationship itself can lead to differential degrees of OS.

\section{Simple and complex cells}

In cat V1, the thalamorecipient layers (layer 4 and upper layer 6) are dominated by simple cells, whereas regions beyond thalamocortical stages of processing such as superficial layers contain mainly complex cells (Gilbert, 1977; Martinez et al., 2005; Hirsch and Martinez, 2006). These laminar distributions of the cell types are consistent with the hierarchical model in which simple cells are constructed by convergent thalamic inputs, and complex cells are built by sampling simple-cell inputs. In mouse $\mathrm{V} 1$, we have previously shown that layer 4 is dominated by monocontrast cells (a special type of simple cell that displays only one spike subfield, either on or off; Liu et al., 2009; Y. T. Li et al., 2014), whereas layer 2/3 contains a large number of conventional simple and complex cells (defined by segregated and overlapping on and off spike subfields, respectively; Fig. $1 F$ ). At the synaptic level, the separation of on and off subfields of these cells exhibited a graded variation (Fig. 2G). These results suggest that simple and complex cells are not necessarily formed at different stages of hierarchical processing, but they can be formed at the same stage of processing within a common circuit (Alonso and Martinez, 1998; Priebe et al., 2004; Liu et al., 2010), likely by pooling monocontrast layer 4 inputs and intralaminar inputs.

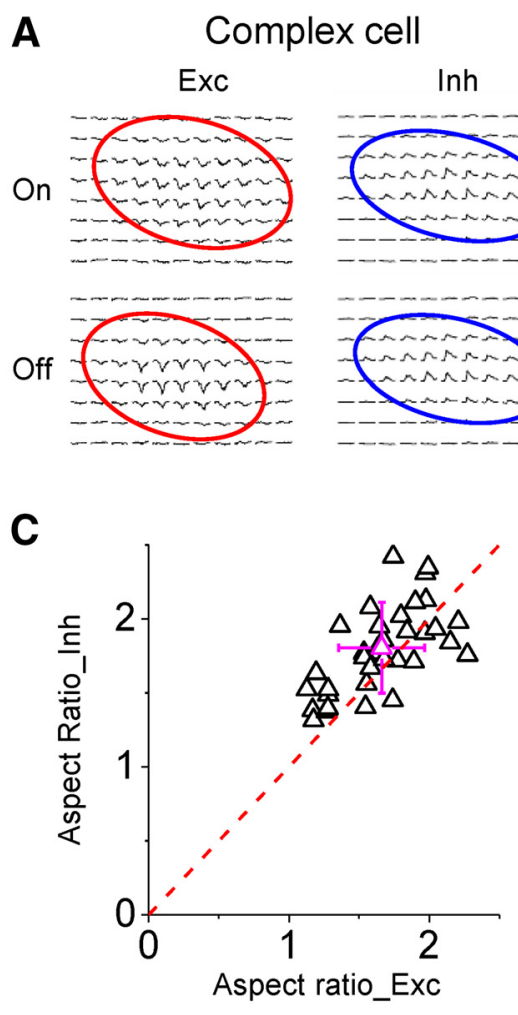

$\mathbf{B}$
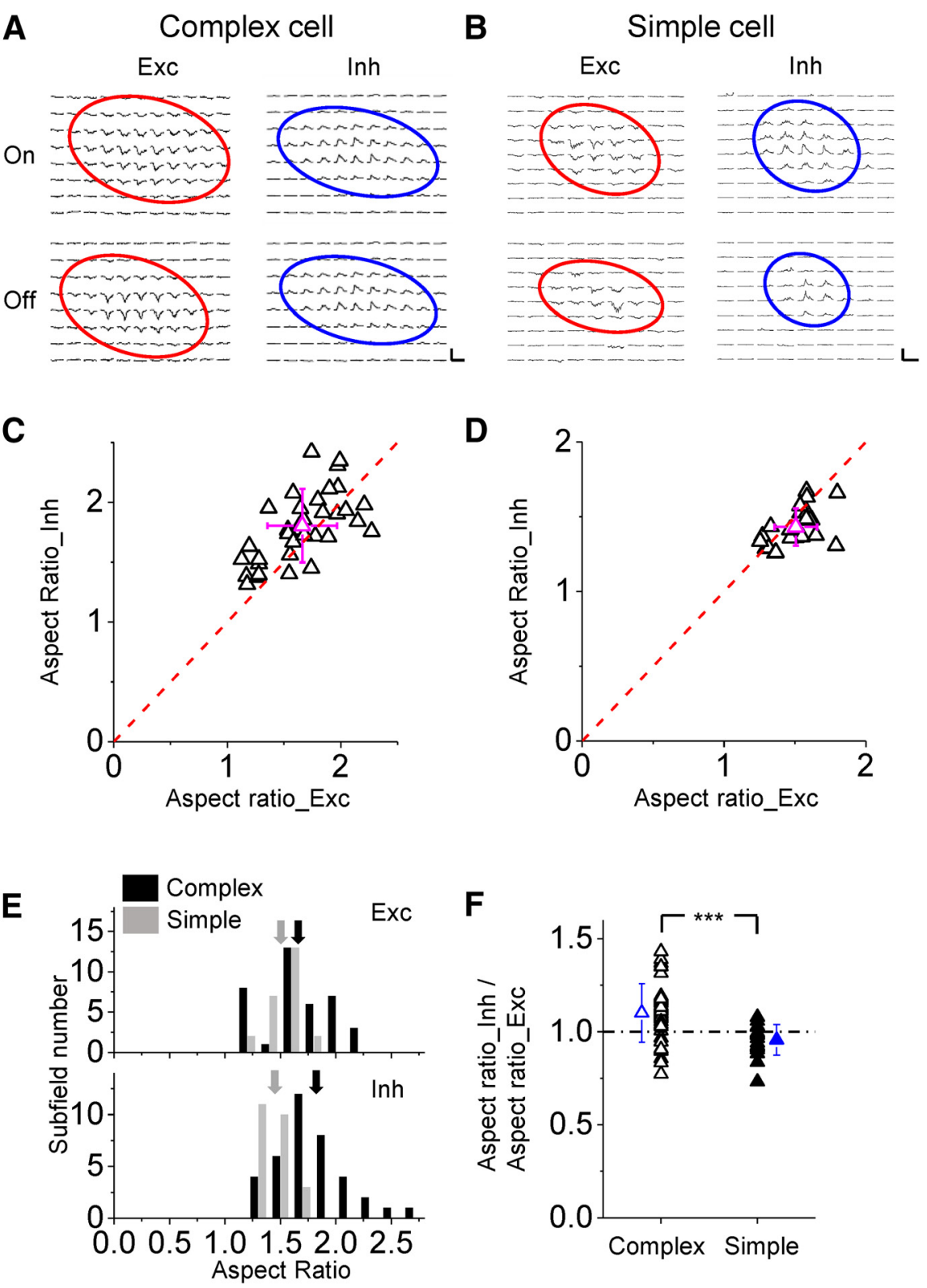

Figure 6. Geometry of synaptic subfields in complex and simple cells. A, Average excitatory and inhibitory responses to flash on and off square stimuli in an example complex cell. Square size is $5^{\circ}$. Ovals depict the elliptic fitting of the synaptic subfields. Scale, 300 pA (Exc)/560 pA (Inh), 300 ms. B, Synaptic RFs for an example simple cell. Scale, 250 pA (Exc)/510 pA (Inh), 300 ms. C, Aspect ratio for inhibitory subfield versus that for the excitatory subfield in the same cell and of the same contrast, plotted for individual complex cells ( $n=38$ pairs of subfields). Magenta symbol displays mean \pm SD. Red dash line is the identity line. $D$, Aspect ratio for inhibitory subfield versus that for excitatory subfield, plotted for individual simple cells ( $n=24$ pairs of subfields). $\boldsymbol{E}$, Distribution of aspect ratios for excitatory (top) and inhibitory (bottom) subfields in complex (black) and simple (gray) cell groups. Arrows indicate the mean values. $\boldsymbol{F}$, Ratios of aspect ratio for inhibitory subfield over that for the excitatory subfield in the same cell and of the same contrast, in complex and simple cell groups. Blue symbols display mean $\pm S D .{ }^{* * *} p<0.001$, two-tailed $t$ test.

It is generally thought that simple and complex cells are about equally selective for orientation. Although there are reports about differential orientation tuning of simple and complex cells, the difference is relatively small. For example, the median tuning bandwidths of simple and complex cells are $40^{\circ}$ and $44^{\circ}$ respectively in macaque V1 (De Valois et al., 1982). In a more recent study in macaque V1, no significant difference in tuning bandwidth has been found between simple and complex cells (Ringach et al., 2002). However, when OS is quantified with a global measure (circular variance), simple cells do exhibit higher OS than complex cells (Ringach et al., 2002). An earlier single-unit study 
in mouse V1 has reported that superficial neurons are highly selective for orientation without distinguishing between simple and complex cells (Niell and Stryker, 2008). In the current study, using a conventional index to measure OS, we found that complex cells are significantly less orientation tuned than simple cells. The functional significance of this differential level of OS is unclear. One possibility is that these V1 cells can provide functionally distinct inputs to different downstream areas, accounting for the functional specialization of these targets (Andermann et al., 2011; Marshel et al., 2011; Glickfeld et al., 2013).

\section{Heterogeneous excitatory/inhibitory tuning relationship}

Tuning properties of sensory cortical neurons are predominantly shaped by excitatory and inhibitory inputs they receive (Isaacson and Scanziani, 2011; Zhang et al., 2011). Our voltage-clamp recording data indicate that excitatory inputs to simple and complex cells do not differ in the degree of orientation tuning, which is consistent with the notion that these two types of cell may receive excitation from a common population of presynaptic neurons. However, they do differ in the tuning of inhibitory input, as well as the relative tuning relationship between excitation and inhibition. Our data in the mouse clearly indicate that excitation and inhibition have similar orientation preferences (Fig. $4 E$; Liu et al., 2011), although in the cat there is still debate as to whether this is the case (Anderson et al., 2000; Monier et al., 2003; Mariño et al., 2005). Under such circumstance, because inhibition is narrower than excitation in complex cells but broader than excitation in simple cells, if we average tuning curves from all the cells we would obtain a result suggesting that excitation and inhibition have similar tuning (Fig. 4C); a conclusion that was made by a previous study (Tan et al., 2011). Therefore, behind a big picture of cotuned or balanced excitation and inhibition (Mariño et al., 2005; Tan et al., 2011), the exact or detailed tuning relationship between excitation and inhibition can be in fact heterogeneous.

\section{Inhibitory influence on tuning of output responses}

Because complex and simple cells do not differ in excitatory input tuning, in synaptic amplitudes at the optimal stimulus orientation, or in intrinsic properties such as the effective spike threshold, their differential selectivity levels must be attributed mainly to the differential inhibitory tuning. Previously we have shown in simple cells that inhibition, while having a similar orientation preference as excitation, plays a critical role in sharpening OS. The sharpening is achieved by not only lowering the level of membrane potential responses in general, but also expanding the input dynamic range and rendering the input-output relationship more linear (Liu et al., 2011). Here, we found that in complex cells, inhibition also has the same orientation preference as excitation. However, inhibition is more sharply tuned than excitation. Such scenario determines that in complex cells, inhibition would have a much weaker or even no sharpening effect compared with simple cells. Indeed, in our neuron modeling when we manipulated the tuning level of inhibition from more broadly tuned to more sharply tuned, the tuning of resulting membrane potential responses became gradually broadened (Fig. $5 F$ ). Our current-clamp recording results confirmed that the tuning of subthreshold membrane potential response is broader in complex than simple cells (Fig. $2 J$ ), and that it is broader compared with excitatory input in complex cells (Fig. 5A). Recently, using dynamic clamp recordings, we also demonstrated in cortical cells that by broadening the sensory tuning of inhibitory input, the tuning of spiking response could be narrowed (Li et al., 2012a;
L.Y. Li et al., 2014). In other words, the tuning of spiking response will be broadened if the tuning of inhibitory input is narrowed. Modulating the inhibitory tuning to shape OS seems a dominant mechanism that also accounts for the contrast invariance of orientation tuning of excitatory cells ( $\mathrm{Li}$ et al., 2012b), and the developmental sharpening of orientation tuning of layer 4 excitatory neurons (Li et al., 2012a).

\section{RF architecture and OS}

A previous study has demonstrated that OS of simple cells can be predicted from the geometry of their RF maps at the membrane potential response level (Lampl et al., 2001). In principle, the spatial organization of synaptic RFs can also contribute to the orientation tuning of complex cells. Here, we found that excitatory subfields in complex cells are slightly but significantly more elongated in complex than simple cells (Fig. 6E). However, the on and off excitatory subfields in simple cells are spatially more separated compared with complex cells, and they are often displayed along the minor axis of the subfields. As demonstrated previously (Lien and Scanziani, 2013), such displacement of on and off excitatory inputs alone will result in orientation tuning. Together, the subfield shape and on/off displacement may render the summed excitatory input to simple cells to have a similar degree of orientation tuning as complex cells.

\section{Potential origin of inhibitory input tuning}

That inhibitory tuning is sharper in complex than simple cells can be explained by two possible mechanisms. First, the presynaptic neurons targeting a complex cell are more sharply tuned than those targeting a simple cell. Inhibitory neurons vary broadly in their tuning selectivity. For example, somatostatin-positive neurons are found to be much more sharply tuned than parvalbumin (PV) positive neurons (Ma et al., 2010). Even in the population of PV neurons which are generally considered broadly tuned (Kerlin et al., 2010; Ma et al., 2010; Hofer et al., 2011), some PV cells can be much more sharply tuned than the others (Runyan and Sur, 2013). In addition, other types of inhibitory neuron (Gonchar et al., 2007; Xu et al., 2010; Rudy et al., 2011) may also be selective for orientation, which remain to be investigated.

Second, even if presynaptic inhibitory neurons are all broadly tuned, an elongated spatial arrangement of their visual RFs can result in sharply tuned summed inhibitory input, in a similar manner as the convergence of untuned thalamic inputs on a simple cell in cat V1 (Reid and Alonso, 1995; Ferster et al., 1996; Alonso and Martinez, 1998; Lampl et al., 2001). That inhibitory subfields are more elongated in complex than simple cells (Fig. $6 E$ ) correlates well with the observation that the inhibitory tuning is sharper in complex than simple cells. Although the difference in inhibitory subfield geometry between complex and simple cells appears somewhat moderate, it can certainly contribute to a difference in inhibitory tuning strength. Together with our previous understanding that inhibitory on and off subfields in simple cells are overlapped similarly as in complex cells (Liu et al., 2010), our data suggest that the way inhibitory neuron RFs are spatially arranged is a likely mechanism underlying the more sharply tuned inhibition in complex cells.

Recent slice recording data demonstrate that inhibitory neurons in general connect with nearby excitatory cells rather densely and promiscuously (Fino and Yuste, 2011; Packer and Yuste, 2011; Pfeffer et al., 2013). These results cast doubts on whether the summed inhibitory input can be sharply tuned. However, that inhibition has the same orientation preference as excitation in complex cells argues against that inhibitory-excit- 
atory neuron connections are entirely nonspecific (Yoshimura and Callaway, 2005; Ohki and Reid, 2007). These findings then raise new questions: why do complex cells have a specific linear arrangement of their inhibitory inputs? What kind of synaptic plasticity mechanism supports the formation of such circuit configuration? Future investigations are needed to answer these intriguing questions.

\section{References}

Alonso JM, Martinez LM (1998) Functional connectivity between simple cells and complex cells in cat striate cortex. Nat Neurosci 1:395-403. CrossRef Medline

Andermann ML, Kerlin AM, Roumis DK, Glickfeld LL, Reid RC (2011) Functional specialization of mouse higher visual cortical areas. Neuron 72:1025-1039. CrossRef Medline

Anderson JS, Carandini M, Ferster D (2000) Orientation tuning of input conductance, excitation, and inhibition in cat primary visual cortex. J Neurophysiol 84:909-926. Medline

Campbell FW, Cleland BG, Cooper GF, Enroth-Cugell C (1968) The angular selectivity of visual cortical cells to moving gratings. J Physiol 198:237250. CrossRef Medline

Carandini M, Ferster D (2000) Membrane potential and firing rate in cat primary visual cortex. J Neurosci 20:470-484. Medline

Carandini M, Heeger DJ, Movshon JA (1997) Linearity and normalization in simple cells of the macaque primary visual cortex. J Neurosci 17:86218644. Medline

De Valois RL, Yund EW, Hepler N (1982) The orientation and direction selectivity of cells in macaque visual cortex. Vision Res 22:531-544. CrossRef Medline

Ferster D, Chung S, Wheat H (1996) Orientation selectivity of thalamic input to simple cells of cat visual cortex. Nature 380:249-252. CrossRef Medline

Fino E, Yuste R (2011) Dense inhibitory connectivity in neocortex. Neuron 69:1188-1203. CrossRef Medline

Gardner JL, Anzai A, Ohzawa I, Freeman RD (1999) Linear and nonlinear contributions to orientation tuning of simple cells in the cat's striate cortex. Vis Neurosci 16:1115-1121. CrossRef Medline

Gilbert CD (1977) Laminar differences in receptive field properties of cells in cat primary visual cortex. J Physiol 268:391-421. CrossRef Medline

Glickfeld LL, Andermann ML, Bonin V, Reid RC (2013) Cortico-cortical projections in mouse visual cortex are functionally target specific. Nat Neurosci 16:219-226. CrossRef Medline

Gonchar Y, Wang Q, Burkhalter A (2007) Multiple distinct subtypes of GABAergic neurons in mouse visual cortex identified by triple immunostaining. Front Neuroanat 1:3. CrossRef Medline

Heggelund P (1986) Quantitative studies of the discharge fields of single cells in cat striate cortex. J Physiol 373:277-292. CrossRef Medline

Henry GH, Dreher B, Bishop PO (1974) Orientation specificity of cells in cat striate cortex. J Neurophysiol 37:1394-1409. Medline

Hirsch JA, Martinez LM (2006) Circuits that build visual cortical receptive fields. Trends Neurosci 29:30-39. CrossRef Medline

Hofer SB, Ko H, Pichler B, Vogelstein J, Ros H, Zeng H, Lein E, Lesica NA, Mrsic-Flogel TD (2011) Differential connectivity and response dynamics of excitatory and inhibitory neurons in visual cortex. Nat Neurosci 14:1045-1052. CrossRef Medline

Hubel DH, Wiesel TN (1962) Receptive fields, binocular interaction and functional architecture in the cat's visual cortex. J Physiol 160:106-154. CrossRef Medline

Ikeda H, Wright MJ (1975) Retinotopic distribution, visual latency and orientation tuning of "sustained" and "transient" cortical neurones in area 17 of the cat. Exp Brain Res 22:385-398.

Isaacson JS, Scanziani M (2011) How inhibition shapes cortical activity. Neuron 72:231-243. CrossRef Medline

Jones JP, Palmer LA (1987) The two-dimensional spatial structure of simple receptive fields in cat striate cortex. J Neurophysiol 58:1187-1211. Medline

Kerlin AM, Andermann ML, Berezovskii VK, Reid RC (2010) Broadly tuned response properties of diverse inhibitory neuron subtypes in mouse visual cortex. Neuron 67:858-871. CrossRef Medline

Lampl I, Anderson JS, Gillespie DC, Ferster D (2001) Prediction of orientation selectivity from receptive field architecture in simple cells of cat visual cortex. Neuron 30:263-274. CrossRef Medline
Li LY, Ji XY, Liang F, Li YT, Xiao Z, Tao HW, Zhang LI (2014) A feedforward inhibitory circuit mediates lateral refinement of sensory representation in upper layer $2 / 3$ of mouse primary auditory cortex. J Neurosci 34:13670-13683. CrossRef Medline

Li YT, Ma WP, Pan CJ, Zhang LI, Tao HW (2012a) Broadening of cortical inhibition mediates developmental sharpening of orientation selectivity. J Neurosci 32:3981-3991. CrossRef Medline

Li YT, Ma WP, Li LY, Ibrahim LA, Wang SZ, Tao HW (2012b) Broadening of inhibitory tuning underlies contrast-dependent sharpening of orientation selectivity in mouse visual cortex. J Neurosci 32:16466-16477. CrossRef Medline

Li YT, Ibrahim LA, Liu BH, Zhang LI, Tao HW (2013) Linear transformation of thalamocortical input by intracortical excitation. Nat Neurosci 16:1324-1330. CrossRef Medline

Li YT, Liu BH, Chou XL, Zhang LI, Tao HW (2014) Strengthening of direction selectivity by broadly tuned and spatiotemporally slightly offset inhibition in mouse visual cortex. Cereb Cortex. Advance online publication. Retrieved March 20, 2014. CrossRef Medline

Lien AD, Scanziani M (2013) Tuned thalamic excitation is amplified by visual cortical circuits. Nat Neurosci 16:1315-1323. CrossRef Medline

Liu BH, Li P, Li YT, Sun YJ, Yanagawa Y, Obata K, Zhang LI, Tao HW (2009) Visual receptive field structure of cortical inhibitory neurons revealed by two-photon imaging guided recording. J Neurosci 29:10520-10532. CrossRef Medline

Liu BH, Li P, Sun YJ, Li YT, Zhang LI, Tao HW (2010) Intervening inhibition underlies simple-cell receptive field structure in visual cortex. Nat Neurosci 13:89-96. CrossRef Medline

Liu BH, Li YT, Ma WP, Pan CJ, Zhang LI, Tao HW (2011) Broad inhibition sharpens orientation selectivity by expanding input dynamic range in mouse simple cells. Neuron 71:542-554. CrossRef Medline

Ma WP, Liu BH, Li YT, Huang ZJ, Zhang LI, Tao HW (2010) Visual representations by cortical somatostatin inhibitory neurons: selective but with weak and delayed responses. J Neurosci 30:14371-14379. CrossRef Medline

Ma WP, Li YT, Tao HW (2013) Downregulation of cortical inhibition mediates ocular dominance plasticity during the critical period. J Neurosci 33:11276-11280. CrossRef Medline

Mangini NJ, Pearlman AL (1980) Laminar distribution of receptive field properties in the primary visual cortex of the mouse. J Comp Neurol 193:203-222. CrossRef Medline

Mariño J, Schummers J, Lyon DC, Schwabe L, Beck O, Wiesing P, Obermayer K, Sur M (2005) Invariant computations in local cortical networks with balanced excitation and inhibition. Nat Neurosci 8:194-201. CrossRef Medline

Marshel JH, Garrett ME, Nauhaus I, Callaway EM (2011) Functional specialization of seven mouse visual cortical areas. Neuron 72:1040-1054. CrossRef Medline

Martinez LM, Wang Q, Reid RC, Pillai C, Alonso JM, Sommer FT, Hirsch JA (2005) Receptive field structure varies with layer in the primary visual cortex. Nat Neurosci 8:372-379. CrossRef Medline

Mata ML, Ringach DL (2005) Spatial overlap of on and off subregions and its relation to response modulation ratio in macaque primary visual cortex. J Neurophysiol 93:919-928. CrossRef Medline

Monier C, Chavane F, Baudot P, Graham LJ, Frégnac Y (2003) Orientation and direction selectivity of synaptic inputs in visual cortical neurons: a diversity of combinations produces spike tuning. Neuron 37:663-680. CrossRef Medline

Moore CI, Nelson SB (1998) Spatio-temporal subthreshold receptive fields in the vibrissa representation of rat primary somatosensory cortex. J Neurophysiol 80:2882-2892. Medline

Niell CM, Stryker MP (2008) Highly selective receptive fields in mouse visual cortex. J Neurosci 28:7520-7536. CrossRef Medline

Ohki K, Reid RC (2007) Specificity and randomness in the visual cortex. Curr Opin Neurobiol 17:401-407. CrossRef Medline

Packer AM, Yuste R (2011) Dense, unspecific connectivity of neocortical parvalbumin-positive interneurons: a canonical microcircuit for inhibition? J Neurosci 31:13260-13271. CrossRef Medline

Pfeffer CK, Xue M, He M, Huang ZJ, Scanziani M (2013) Inhibition of inhibition in visual cortex: the logic of connections between molecularly distinct interneurons. Nat Neurosci 16:1068-1076. CrossRef Medline

Priebe NJ, Ferster D (2008) Inhibition, spike threshold, and stimulus selectivity in primary visual cortex. Neuron 57:482-497. CrossRef Medline 
Priebe NJ, Mechler F, Carandini M, Ferster D (2004) The contribution of spike threshold to the dichotomy of cortical simple and complex cells. Nat Neurosci 7:1113-1122. CrossRef Medline

Reid RC, Alonso JM (1995) Specificity of monosynaptic connections from thalamus to visual cortex. Nature 378:281-284. CrossRef Medline

Ringach DL, Shapley RM, Hawken MJ (2002) Orientation selectivity in macaque V1: diversity and laminar dependence. J Neurosci 22:5639-5651. Medline

Rose D, Blakemore C (1974) An analysis of orientation selectivity in the cat's visual cortex. Exp Brain Res 20:1-17. Medline

Rudy B, Fishell G, Lee S, Hjerling-Leffler J (2011) Three groups of interneurons account for nearly $100 \%$ of neocortical GABAergic neurons. Developmental neurobiology 71:45-61. CrossRef Medline

Runyan CA, Sur M (2013) Response selectivity is correlated to dendritic structure in parvalbumin-expressing inhibitory neurons in visual cortex. J Neurosci 33:11724-11733. CrossRef Medline

Schiller PH, Finlay BL, Volman SF (1976) Quantitative studies of single-cell properties in monkey striate cortex: II. Orientation specificity and ocular dominance. J Neurophysiol 39:1320-1333. Medline

Skottun BC, De Valois RL, Grosof DH, Movshon JA, Albrecht DG, Bonds AB (1991) Classifying simple and complex cells on the basis of response modulation. Vision Res 31:1079-1086. CrossRef Medline

Sun YJ, Wu GK, Liu BH, Li P, Zhou M, Xiao Z, Tao HW, Zhang LI (2010)
Fine-tuning of pre-balanced excitation and inhibition during auditory cortical development. Nature 465:927-931. CrossRef Medline

Tan AY, Brown BD, Scholl B, Mohanty D, Priebe NJ (2011) Orientation selectivity of synaptic input to neurons in mouse and cat primary visual cortex. J Neurosci 31:12339-12350. CrossRef Medline

Watkins DW, Berkley MA (1974) The orientation selectivity of single neurons in cat striate cortex. Exp Brain Res 19:433-446. Medline

Wehr M, Zador AM (2003) Balanced inhibition underlies tuning and sharpens spike timing in auditory cortex. Nature 426:442-446. CrossRef Medline

Xu X, Roby KD, Callaway EM (2010) Immunochemical characterization of inhibitory mouse cortical neurons: three chemically distinct classes of inhibitory cells. J Comp Neurol 518:389-404. CrossRef Medline

Yoshimura Y, Callaway EM (2005) Fine-scale specificity of cortical networks depends on inhibitory cell type and connectivity. Nat Neurosci 8:1552-1559. CrossRef Medline

Zhang LI, Tan AY, Schreiner CE, Merzenich MM (2003) Topography and synaptic shaping of direction selectivity in primary auditory cortex. Nature 424:201-205. CrossRef Medline

Zhang LI, Zhou Y, Tao HW (2011) Perspectives on: information and coding in mammalian sensory physiology: inhibitory synaptic mechanisms underlying functional diversity in auditory cortex. J Gen Physiol 138:311320. CrossRef Medline 